\title{
Do Private Firms Outperform SOE Firms after Going Public in China Given their Different Governance Characteristics?
}

\author{
Shenghui Tong, and EddyJunarsin ${ }^{b+*}$ \\ ${ }^{2}$ Chinese Academy of Finance and Development, CentralUniversity of Finance and Economics, China \\ ${ }^{b}$ Faculty of Economics and Business, Universitas Gadjah Mada, Indonesia
}

\begin{abstract}
This study examines the characteristics of board structure that affect Chinese public firm's financial performance. Using a sample of 871 firms with 699 observations of previously private firms and 1,914 observations of previously state-owned enterprise (SOE) firms, we investigate the differences in corporate governance between publicly listed firms that used to be pure private firms before going public and listed firms that used to be SOEs before their initial public offerings (IPOs). Our main finding is that previously private firms outperform previously SOE firms in China after IPOs. In the wake of becoming listed firms, previously SOE firms might be faced with difficulties adjusting to professional business practices to build and extend competitive advantages. In addition, favorable policies and assistance from the government to the SOE firms might have triggered complacency, especially in early years after getting listed. On the other hand, professional savvy and acumen, combined with efficiency and favorable business climate created by the government have probably led the previously private firms to improve their values stronger and faster.
\end{abstract}

\begin{abstract}
Penelitian ini menguji karakteristik struktur dewan direktur yang mempengaruhi kinerja keuangan perusahaan publik di Cina. Penelitian ini menggunakan sampel 871 perusahaan dengan 699 observasi perusahaan yang sebelumnya perusahaan swasta murni dan 1.914 observasi perusahaan yang sebelumnya badan usaha milik negara (BUMN). Kami menginvestigasi perbedaan-perbedaan dalam tata-kelola perusahaan antara perusahaan publik yang sebelumnya perusahaan swasta murni menjadi perusahaan public, dengan perusahaan publik yang sebelumnya perusahaan-perusahaan BUMN pra penawaran saham perdana mereka di bursa efek. Temuan utama kami adalah bahwa perusahaan publik yang sebelumnya adalah perusahaan swasta murnilebih unggul dalam hal kinerja daripada perusahaan publik yang sebelumnya adalah perusahaan-perusahaan BUMN setelah menjadi perusahaan publik di bursa efek. Setelah penawaran saham perdana, perusahaan publik yang sebelumnya adalah perusahaan-perusahaan BUMN tampaknya menghadapi kesulitan dalam beradaptasi dengan praktik-praktik bisnis profesional untuk membangun dan melebarkan keunggulan kompetitif. Selain itu, kebijakan-kebijakan yang menguntungkan dan bantuan
\end{abstract}

\footnotetext{
${ }^{+}$We are grateful for reviews and comments from Dr. Wallace Davidson and two anonymous referees.
} 
dari pemerintah untuk mantan BUMN barangkali telah memicu keterlenaan, terutama pada tahun-tahun awal setelah terdaftar di bursa efek. Di sisi lain, keahlian dan kemampuan profesional, bersama dengan efisiensi dan iklim bisnis yang kondusif telah mendorong perusahaan publik yang dulunya perusahaan swasta murni untuk meningkatkan nilai mereka dengan lebih kuat dan cepat.

Keywords: Chinese listed firms; corporate governance; firm performance; initial public offerings; private firms; state-owned enterprises

JEL classifications: G30, G34, G38.

\section{Introduction}

Despite the extensive growth of the Chinese economy, the corporate governance systems for Chinese firms are still at the early stage. Establishing an efficient corporate governance system for Chinese firms has become a pressing issue. The major challenge for corporate governance reform is that China started its governance reform efforts in an environment where most of the elements of a well-functioning financial market were not in place. The Chinese government currently encourages continuous improvements in this area, with particular attention to improving shareholder rights and efficiency of governance. Lu et al. (2009) find that Chinese companies have been making governance progress, and improvements in SOEs have resulted in some initial signs of success. Previous studies have also shown that corporate governance improvements enhance firm value in China (Bai et al. Zhang 2004). Xu (2000) finds that the reform of SOEs in China has significantly strengthened incentives, and that productivity has increased.

Discussing governance in China requires some historical perspectives. Listed companies on the Chinese stock markets stem from two original forms. The first is private firms, which are essentially the same as private firms elsewhere. The other form is SOE firms, which are fully owned by the Chinese government and usually managed by government-appointed officials either before or after they are listed on stock exchanges. SOE firms were the only business form in China until the early 1980s. Due to government support, SOE firms are usually larger and have more resources than do private firms. Originally, Chinese private firms have been allowed to operate in China only after 1980s, and they were usually small and constrained by a variety of regulations. Although both types of firms are now public, their differences remain substantial, ranging from firm size, market share, lines of business, competitiveness, and most importantly corporate governance efficiency.

The structure of an SOE firm has resulted in complex governance issues with regard to board structure and board independence. China has adopted a quasi two-tier board structure comprised of a board of directors as well as a supervisory board. However, supervisory directors are not involved in the selection of the directors and managers, and lack the authority to supervise them effectively. In addition, the state and majority shareholders (which are usually government agencies, holding more than half of the total outstanding shares of the listed firms) still play a dominant role in the appointment of independent directors, chairperson, $\mathrm{CFO}$, 
and senior executives. Suggestions to improve the structure of the board include increasing the number of independent directors and establishing a fully independent audit committee. We argue that more attention should be paid to independent directors who have professional and managerial experiences and possess certain levels of financial skills, such as lawyers, financial analysts, and accountants.

Minority shareholders in Chinese companies are a highly fragmented group of individuals. Institutional investors are small players on the Chinese stock markets. Retail investors in China, as in other markets around the world, often lack investment knowledge and awareness of shareholder rights. In China, it is difficult for individual investors to enforce any legal rights against a listed company for negligence or fraud. In this situation, if independent directors can fulfill their duties for the interest of shareholders, especially minority shareholders, the efficiency of corporate governance will be enhanced substantially. It has been suggested that the provision of efficient managerial incentives may be a crucial ingredient in the transformation of SOEs into more profitable modern firms. The Chinese government is promoting equitybased pay as one of the components of compensation because it is considered a way to motivate growth in the capital markets.

In light of the specific characteristics of corporate governance of Chinese listed firms, there are good reasons to conjecture that the effectiveness of corporate governance might differ between the practices in developed markets and those in China. These corporate governance characteristics enumerated above are often thought to be associated with poor corporate governance, which have been ascertained in previous studies (Gibson 2003; La Porta et al. 1998).
Based on the discussion above, we address three issues in this paper. First, what are the board characteristics that affect the financial performance of listed firms in China? Second, due to historical differences between SOE firms and private firms before they went public, do private firms outperform SOE firms, or the other way around, after going public? Third, does the relation between firm value and governance variables is affected by the types of firm (i.e., whether they were previously private firms or previously SOE firms).

In summary, our study finds that previously private firms outperform previously SOE firms in China after IPOs. In the wake of IPOs, previously SOE firms might be having difficulties adjusting to professional business practices (e.g., hiring high-caliber executives and directors, revising company vision or policy, changing business models toward customer satisfaction, etc.) to establish and leverage competitive advantages. Moreover, favorable policies and enormous assistance from the government to the SOE firms might have created complacency, especially in the early years after becoming listed firms. On the other hand, business savvy and acumen, combined with efficiency and conducive business climate provided by the government, have probably led the previously private firms to improve their values more strongly and faster.

We find evidence that adding more directors on the board benefits the previously SOE firms. More educated directors are linked to improving firm performance of previously SOE firms after going public, and the positive relation of firm performance to education has a stronger magnitude for previously private firms. Subsequently, higher board independence benefits both types of firms. For a previously private firm, a higher proportion 
of independent directors on the board is linked to an increased Tobin's Q with a higher magnitude than the equivalent increase for a previously SOE firm. Higher shareholding by top three executives or directors would lead to increasing firm value, but this relation is only significant for previously SOE firms. Next, having more board meetings is valuable to both previously SOE and previously private firms, with the benefit being enhanced in the case of previously private firms. Higher executive compensation is more likely to be accompanied by higher firm performance for previously SOE firms, but not significantly found for previously private firms.

Our study also finds that the proportion of directors who used to work as government officials has no relation with firm performance of previously SOE firms, implying that after IPOs the external market plays a more pivotal role, which leads to more professional business practices in those firms. On the other hand, this relation is significantly positive for previously private firms. Accordingly, previously private firms in China may enjoy the benefits of hiring directors with a government official or bureaucrat background, such as getting access to government projects, business acquaintances, etc. For previously $\mathrm{SOE}$ firms, the advantages of employing this type of directors is less pronounced as these firms basically had been controlled by the government, and had enjoyed all government projects, facilities, and information.

There have been numerous studies that examined the efficiency of corporate governance of public Chinese firms. However, to the best of our knowledge, none of the extant literature has compared the governance of Chinese firms based on their backgrounds, whether they were private firms or SOEs in origin. Our study contributes to the literature on corporate governance systems in China shedding light on the differences in corporate governance between previously private firms and previously SOE firms after they both get listed on the Chinese stock markets. Our study extends Tong and Junarsin's (2013) research on corporate governance in China. We use a more specific sample and employ different methodologies.

The remainder of this paperis organized as follows. Section 2 reviews the literature on corporate governance of Chinese listed firms. Data collection, research design, and variable descriptions are expounded in Section 3. Section 4 discusses empirical methods and results. Eventually, Section 5 concludes.

\section{Literature Review on Corporate Governance of Chinese Firms}

Research on corporate governance has intensified in the wake of infamous financial fraud scandals of Enron, WorldCom, and Parmalat, which were blamed on poor corporate governance (Johnson et al. 2000). The study on corporate governance in emerging markets is important as institutional investors have identified it as a key factor affecting their willingness to invest in those markets. In this setting, to adopt corporate governance systems of Western market economies, the Chinese government has promulgated a series of laws and regulations of corporate governance. These reforms have just been in place relatively recently, and it is still an evolving process. The evolving governance circumstances provide a unique opportunity to examine current governance practices in China, and to identify effective mechanisms. 
The largest firms in China are SOE firms, which were established and run by appointed officials from the government. Among the SOE firms, some of them have gone public. Nevertheless, even after going public, their governance is still similar to that of non-public SOE firms. For instance, after going public, the SOE firms still enjoy supports from the government or government agencies in a variety of ways (Liu 2005). This unique feature gives the SOE firms an edge in competing with private firms. However, the management of SOE firms is still appointed by the government, although their boards of directors are normally elected by shareholders. On the contrary, private firms in China fit the typical image of a private firm elsewhere, and more importantly, their governance is largely independent from the government. For example, Liu (2005) describes how the Chinese stock markets were organized by the government as a vehicle for its SOEs to raise capital and improve operating performance. Since the initial primary objective of the equity markets in China was to help SOEs overcome external financing constraints, governance regulations that have been introduced tend to favor SOEs. Shleifer and Vishny (1998) propose the "grabbing hand" argument that bureaucrats/politicians extract resources from the listed SOEs under their control to fulfill objectives that are not consistent with firm value maximization.

With regard to studies on corporate governance in private firms after going public, Ren and Peng (2008) provide evidence that private firms have improved their efficiency in corporate governance although the improvement in financial performance has not been ascertained. Wang and Shao (2007) argue that stock ownership concentrated in the hands of blockholders affects the efficiency of corporate governance, and private firms are lacking in the efficient restriction systems on blockholders. $\mathrm{Li}$ (2008) documents that inside owners do not necessarily bring benefit to firm value, and even worse, inside owners could undermine the firm value by taking advantage of individual shareholders. Meanwhile, Huang et al. (2006) find that the proportion of independent directors on private firms' boards is relatively higher than that on SOE firms.

Liu (2005) documents that current corporate governance practices in Chinese firms can be best described under a control-based model, which strikingly contrasts with the market-oriented model commonly found in the U.S. and U.K. Sun and Tong (2003) find that share issue privatization is associated with improved corporate performance. Bai et al. (2004) show evidence that the CEO being the Chairperson or Vice Chairperson of the board, and the largest shareholder being the government, have negative effects on firm value. Hence, we conjecture that:

\section{$H_{1}$ : Previously private firms outperform previously SOE firms after they both go public.}

A market-oriented governance model might eventually take place in China. During this process, Chinese firms' governance systems will gradually turn out to be similar to the systems in developed nations, such as the U.S. Private firms are naturally closer to this ultimate goal considering their inherent governance characteristics. Our study purports to investigate the differences in corporate governance between publicly listed firms that used to be pure private firms before going public and public firms that used to be pure SOEs before their IPOs. Whether private firms outperform SOE firms, or vice versa, in the realm of corporate governance is an empirical question. 
For instance, large boards have been associated with less effective monitoring (Core et al. 1997; Jensen 1993; Yermack 1996). Sun and Zhang (2000) find that board size is negatively related to Tobin's Q for Chinese firms. If increased board size leads to less effective monitoring, we would expect firm performance to be the negatively associated with board size. However, for previously SOE firms, a larger board might provide more expertise and strategic human capital much needed to reform those companies. So, our hypotheses are:

\section{$H_{2 A}$ : Board size is negatively related to firm perfor- mance for previously private firms. \\ $H_{2 B}$ : Board size is positively related to firm perfor- mance for previously SOE firms.}

Subsequently, board meeting frequency has been identified as an important dimension of board mechanisms. However, whether high board meeting frequency is favorable to firm performance remains undetermined due to mixed evidence. Lipton and Lorsch (1992) suggest that the most widely shared problem faced by directors is the lack of time to carry out their duties. Similarly, Conger et al. (1998) suggest that a board meeting is an important resource to improve the effectiveness of the board. An implication of those findings is that directors that meet more frequently are more likely to perform their duties in line with shareholders' interests. However, based on a sample of Fortune 500 firms, Vafeas (1999) documents that the annual number of board meetings is inversely related to firm value, although he further finds that operating performance improves following the years of abnormal board activity. Listed firms in China are still at the transitional stage; thus, for those directors without accumulated experiences in running or supervising a listed firm, we expect the benefits of more meetings to outweigh the costs. Therefore, we conjecture that board meeting frequency is positively related to firm performance.

$H_{3}$ : Board meeting frequency is positively related to firm performance for both previously private firms and previously SOE firms.

There are two potential approaches that might achieve the required systems of corporate governance in a transitional economy: (1) a privatization approach and (2) a government-controlled approach. Empirical evidence indicates that privatization has benefited Chinese public firms. For example, Zhang and Zhang's (2003) findings show that private firms outperform SOEs in operational efficiency, profitability, capital structure, and market evaluation; however, due to a wide range of firm qualities of these private firms, the potential risk of investing in these private firms is high as well. On the other hand, the government-controlled approach has been advocated by Qian (1995). He argues that the circumstances probably do not allow for the achievement of pure privatization in present day China. The SOEs owned by local governments in China could report outstanding financial performances, although the financial reports of those SOEs have been possibly somewhat cooked before they are disclosed to the public. Obviously, this is not the optimal system.

Considering the complexity of current corporate governance systems in China, it is compelling to examine the functions and roles of independent directors in Chinese listed firms. Traditionally, an independent director is defined as a director who has no affiliation with the firm except his or her directorship (Clifford and Evans 1997), and so the independent directors are defined in the same way in this paper. Gao and Kling (2008) find that outsiders on the board of directors can pre- 
vent operational tunneling. In another place, Abidin et al. (2009) show that for Malaysian firms, the ratio of independent non-executive directors on the board has a positive impact on firm performance. Having independent non-executive directors on the board would help monitor and control the opportunistic behavior of management (Jensen and Meckling 1976). Furthermore, Brickley and James (1987) argue that outside directors also contribute to reducing management consumption of perquisites.

Empirically, studies on the association between independent directors and firm performance have shown mixed findings although most results are still in favor of having more independent directors on the board. For instance, Dahya and McConnell (2003) present evidence that investors appear to view the appointments of outside CEOs as good news in the U.K., and this is reflected in the announcement period stock returns. Furthermore, Lee et al. (1999) find that the appointment of a financial outside director to the board of a public corporation is associated with positive abnormal returns among medium-sized firms. In contrast, there are also studies that find a negative association between independent non-executive directors and firm performance. Several other studies show that independent non-executive directors do not necessarily have a positive impact on firm performance (Agrawal and Knoeber 1996; Bhagat and Black 1999), implying that in some cases the independent non-executive directors do not play their roles effectively. In addition, Firth et al. (2008) find that boards with a majority of outside directors are not associated with lower agency costs. Nevertheless, the finding of our study substantiates the independent directors system.
The traditional perspective on independent directors opines that more independent directors on the board monitor the firm more effectively. According to the selection procedures for independent directors in China, the independent directors are actually "outside directors." Huang et al. (2006) do not confirm the significant relation between board independence and firm performance. Fama and Jensen (1983) argue that outside directors have an incentive to act as monitors of management since they want to protect their reputation as effective independent decision makers. Weisbach (1988) finds that boards dominated by outsiders are more likely to replace CEOs than do insider-dominated boards. The presence of outside directors who fulfill their monitoring duties could make the degree of exposure to the market for corporate control less important. Empirical evidence also shows that firm performance is linked to board composition (Brickley and James 1987; Byrd and Hickman 1992; and Rosenstein and Wyatt 1990). Those studies consistently confirm that firm performance is superior when outside directors hold a significant percentage of board seats. Therefore, we conjecture that more independent directors on the board serve the firm better.

$\mathrm{H}_{4}$ : Board independence is positively related to firm performance for both previously private firms and previously SOE firms.

Johnson et al. (2001) find that after SOE firms go public, government regulations could serve as an effective governance mechanism, especially when the law and law enforcement are weak. In China, since the legal infrastructure is particularly weak, Pistor and $\mathrm{Xu}$ (2005) argue that the so-called "administrative governance" has played an active and positive role in the development of Chinese stock markets. However, more re- 
cent evidenceindicates that government regulations are also the source of many problems. For instance, Fan et al. (2007) find that firms with politically connected CEOs are more likely to have boards populated by current or former government bureaucrats. The accounting and stock return performances of the firms run by politically connected CEOs are poor relative to their politically unconnected counterparts. Moreover, in a related study, Chan et al. (2004) find that politicians and state-controlling owners in China occupy most board seats, and almost 50 percent of the directors are appointed by the state-controlling owners while another 30 percent are affiliated with various layers of government agencies. There are a relatively limited number of professionals (lawyers, accountants, or finance experts) on Chinese boards.

$H_{5}:$ Politically-connected board is negatively related to firm performance for both previously private firms and previoushy SOE firms.

How to select independent directors has become a critical issue for Chinese firms. Accordingly, it is of importance to investigate the backgrounds of incumbent directors in order to find the most suitable candidates for the independent director positions. Our study takes into account whether independent directors have accounting expertise or are hired from academia, and investigates the relation between those characteristics and firm performance. Accounting skills will furnish independent directors with the expertise to analyze financial statements and monitor financial decision-making in the firm. Hiring independent directors from academia has become a routine practice in China. Academic directors may have skills that would greatly benefit the firm they serve. The academic fields of those independent directors are usually related to the lines of business of the hiring firm. Therefore, those independent directors should comprehend the business to a sufficient extent. Kroszner and Strahan (2001) find that board members with a banking background are effective monitors since bankers have the expertise in strategic and financial management. We, therefore, believe that directors with academic, accounting, and banking backgrounds would be effective monitors.

$H_{6}:$ A board with more directors having academic, accounting, and banking backgrounds is positively related to firm performance for both previously private firms and previously SOE firms.

It has been shown by a vast array of empirical evidence that for Chinese listed firms, duality is negatively related to firm performance (Wu 2002; Pu and Liu 2004). Wu et al.'s (1998) paper substantiates the notion that there is a positive relationship between duality and firm size. Bai et al. (2004) find that the CEO being the Chairperson or Vice Chairperson of the board has a negative effect on firm value. Subsequently, Huang et al. (2006) find that duality is more likely to prevail in private firms than in SOE firms. One of the reasons is due to the history of private firms whose founders usually continue dominating the firm even after they have gone public. Therefore, holding both Chairperson and CEO position is not unusual in private firms. However, although a founder can hold dual positions, he or she is not necessarily competent in managing the firm. Instead, the CEO would have enormous power or excessive clout that might be abused. Therefore, we expect the duality to be negatively related to firm performance.

$H_{\dot{f}} \mathrm{CEO} /$ Chair duality is negatively related to firm performance for both previously private firms and previously SOE firms. 
Managerial ownership is another factor often considered in research on corporate governance. Studies in the literature include those that examined the cross-sectional relation between ownership and board characteristics and measures of firm performance (Morck et al. 1988; Yermack 1996), and those that investigated the influence of ownership and board characteristics on specific decisions (Weisbach 1988). Denis and Sarin (1999) find that ownership is weakly related to the changes in firm-specific determinants of ownership and board structure. Meanwhile, Core and Larcker (2002) argue that a mandatory increase in suboptimal equity ownership for executives is associated with the increase in subsequent firm performance. Research on this area for Chinese firms in general finds mixed evidence of the significant relation between ownership structure and firm performance. As stock options and other similar equity-based compensation measures are increasingly implemented in China, we expect that there is a positive relationship between managerial ownership and firm performance.

$H_{8}:$ Managerial ownership is positively related to firm performance for both previously private firms and previously SOE firms.

Although not examined much in previous literature, director age might be an important factor in governance. It is apparent that older directors are usually more experienced, having accumulated great amount of knowledge and skills in business management. Therefore, we expect that the older the average age of the board members, the better the firm performance will be.

$H_{g}$ : Director age is positively related to firm performance for both previously private firms and previously SOE firms.
Similarly, we conjecture that the differences in educational backgrounds of directors are a key factor since well-educated directors could fulfill their duties better than those directors who do not possess sufficient educational trainings. In this study, we define a well-educated director as one who holds a bachelor's degree (or above). We expect that the higher the educational levels of the firm's directors, the better is the firm performance. $H_{10}$ : Director education is positively related to firm performance for both previously private firms and previously SOE firms.

The last key factor that we test is executive compensation. Some research (e.g., Coughlan and Schmidt 1985; Jensen and Murphy 1990) on executive compensation has dealt with the issue of the relation between executive compensation and firm performance, and those studies show that firm performance is largely and positively related to pay-for-performance sensitivity after controlling for risk. For Chinese firms, the relation between executive compensation and firm performance remains unexplored. We expect that higher compensation motivates the management to deliver better firm performance.

$H_{11}$ : Executive compensation is positively related to
firm performance for both previously private
firms and previously SOE firms.

As discussed, these two types of firms are quite different. Hence, we categorize our sample firms into two groups based on this criterion. We then compare their corporate governance effectiveness and efficiency. The relation between firm performance and various board characteristics in these two types of firms is investigated, and indeed this study confirms the differences between their board characteristics. 


\section{Data and Variables}

We collected sample firms and accounting data from $W i n d$, which is a premier financial database on Chinese firms. We selected our sample over the years of 2005-2008. In accordance with our research objective, we categorize our sample into two groups: (1) previously private firms and (2) previously SOE firms. Our final sample consists of 871 firms with 699 observations of previously private firms and 1,914 observations of previously SOE firms. Data on all board characteristics were collected from several board research databases, including Wind and GTA databases.

\section{Dependent Variable}

Our measure of firm performance is Tobin's Q, computed as the sum of total assets with the difference between market value of equity and book value of equity, then divided by book value of assets. Our measure of Q is similar to that used in Wei et al. (2005). Tobin's Q is probably the most often used valuation measure in empirical research on corporate finance. Yermack (1996) and Fan et al. (2007) utilized Q to proxy for firm performance, and find it to be an ideal measure for firm performance. Hence, we employ Q as the proxy for firm performance in this study. We also use return on equity (ROE) as an alternative proxy for firm performance, and replicate the whole analysis process. We find that the results essentially remain the same.

\section{Independent and Control Variables}

We have selected corporate governance variables found by previous studies to be relevant to corporate governance of Chinese listed firms. These variables include firm size, board size, firm market value, return on assets (ROA), board meeting frequency, the proportion of independent directors on the board, CEO/Chairman duality, managerial ownership, the proportion of independent directors who have accounting background, the proportion of independent directors from academia, the educational backgrounds of board members, and executive compensation. The definitions of these variables are reported in the Appendix and discussed briefly below.

Proxies for our independent and control variables are as follows. Board size is measured as the log of the number of directors on the board. Board meeting frequency is measured as the log of the number of board meetings in a certain year. Subsequently, board independence is the percentage of independent directors on the board. We define duality using a dummy variable that takes the value of one if the CEO and the Chair are the same person, and zero otherwise. Managerial ownership is estimated using the $\log$ of shareholding by the top three most highly paid executives or directors. Director expertise represents the percentage of directors with special qualifications. For instance, a board's accounting expertise is measured as the percentage of directors with accounting background. Another example, a board's law 
expertise is measured as the percentage of directors practicing law. Politically-connected board is gauged as the percentage of directors who still or used to work as government officials. Director age is the log of the average age of directors on the board. We measure director education as the proportion of directors with a college degree. Another key variable, i.e., executive compensation is proxied by the log total compensation for the top three most highly paid executives and the $\log$ compensation for the top three most highly paid directors.

Meanwhile, our control variables are firm size, market value, ROA, and growth. Firm size is proxied by log total assets. Market value is market capitalization, which is stock price multiplied by shares outstanding. ROA is estimated as earnings before interest and taxes divided by total assets. Finally, firm growth is measured as the growth rate of the firm's sales.

\section{Empirical Results}

We employ both univariate and multivariate analyses in our tests. For the univariate analysis, we divide the sample into previously private firms (henceforth "private firms"). The sample comprises 871 firms with 699 observations of private firms and 1,914 observations of public firms. We compare the variables for public and private firms using the independent sample $t$-tests. Table 1 below summarizes the univariate analysis findings.

\section{Univariate Analysis}

Univariate analysis in Table 1 shows that public firms indeed differ from private firms in many characteristics. Board size is on average smaller for private firms than for public firms, and the difference is significant at 1 percent level. Directors of private firms are, on average, younger than those of public firms. Meanwhile, the proportion of directors holding college degrees and/or graduate education is significantly higher for public firms than for private firms. Subsequently, private firms are more likely to use the duality system (CEO and Chairman being the same person) than public firms. However, the proportion of independent directors on the board is significantly larger for private firms than that for public firms.

With respect to insider ownership, shareholding by top three executives/board members is significantly higher for private firms. Likewise, executive/board meetings within a year are significantly more frequent for private firms. Interestingly, average compensation of top three most highly paid executives is significantly and much larger for public firms. This is perhaps supported by the fact that public firms are significantly bigger than private firms in terms of market value as well as assets. Nevertheless, Tobin's Q of private firms is significantly higher than that of public firms, suggesting that private firms have more growth opportunities although we do not find a significant difference in sales growth between the two types of companies. 


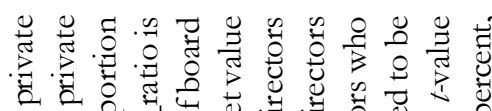

等

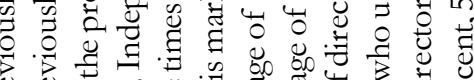

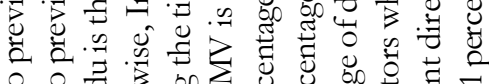
요의

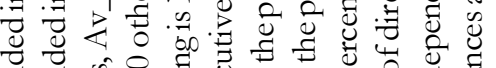

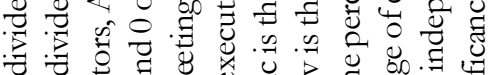

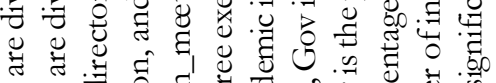

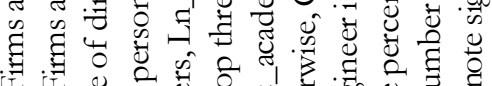

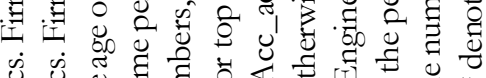
伦

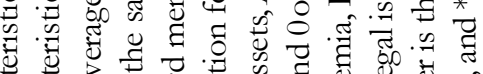

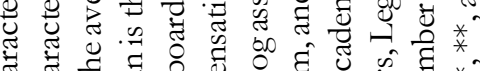

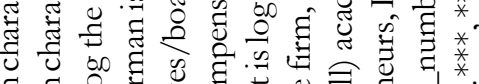

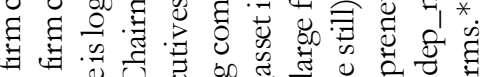
可 의

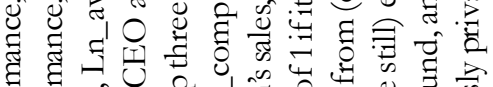

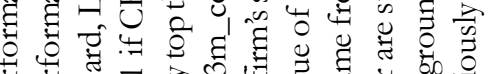

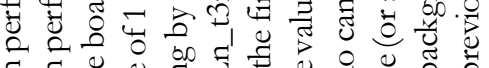

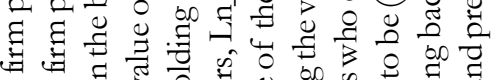

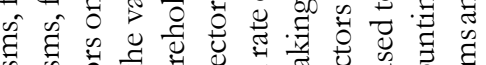
至.

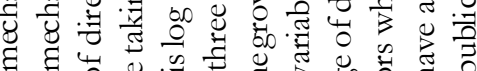
ह

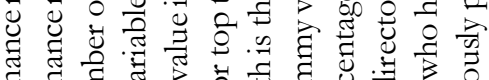
空 or of of

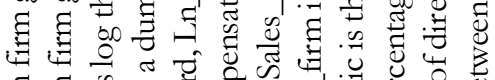

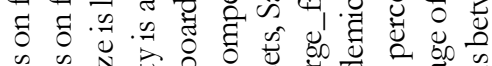

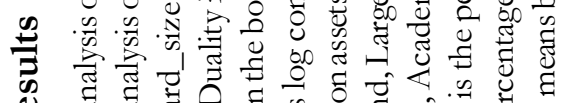
क्ष

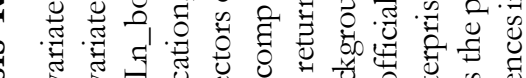

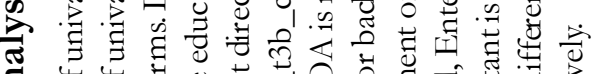

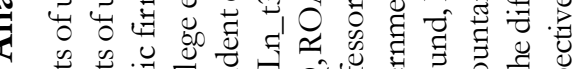

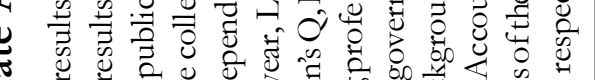

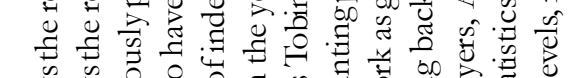

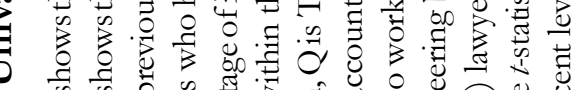

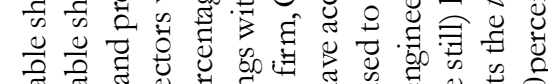

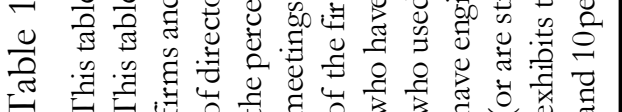

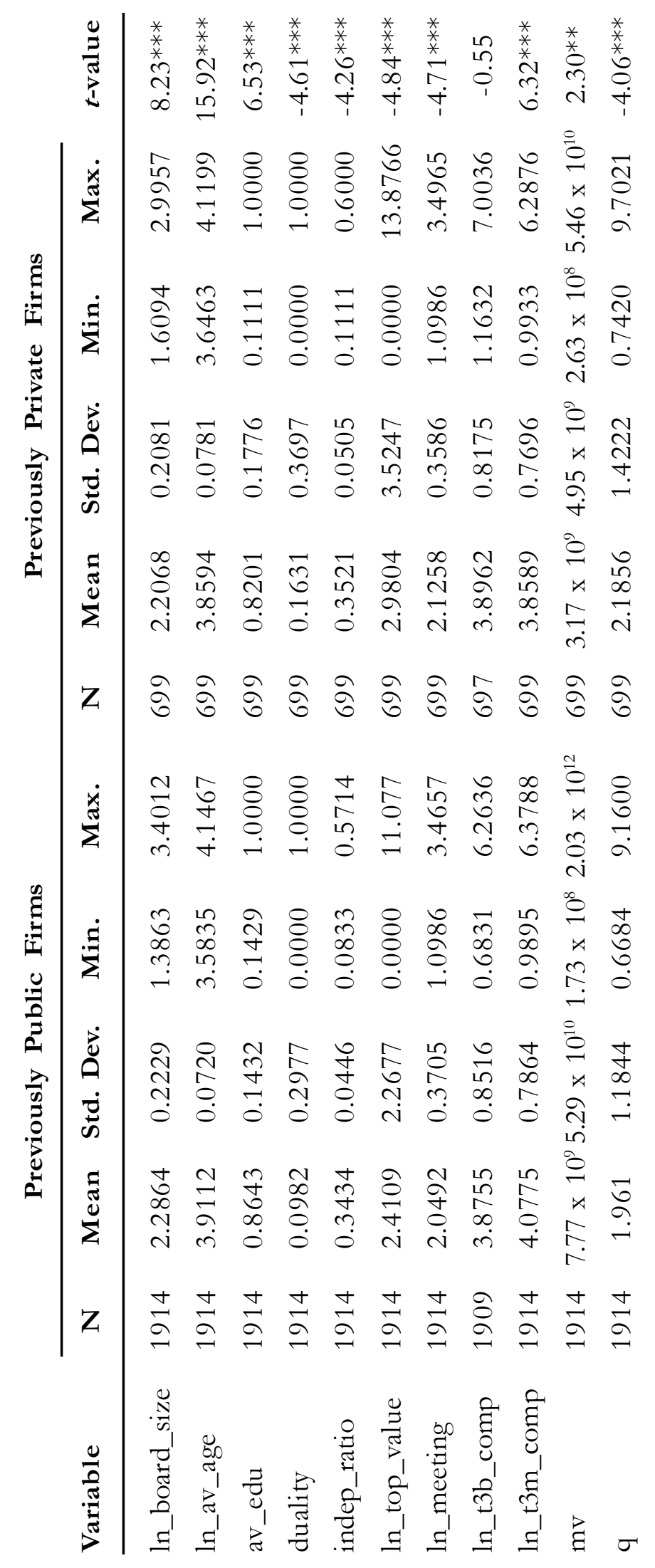


Gadjah Mada International Journal of Business - May-August, Vol. 15, Na 2,2013

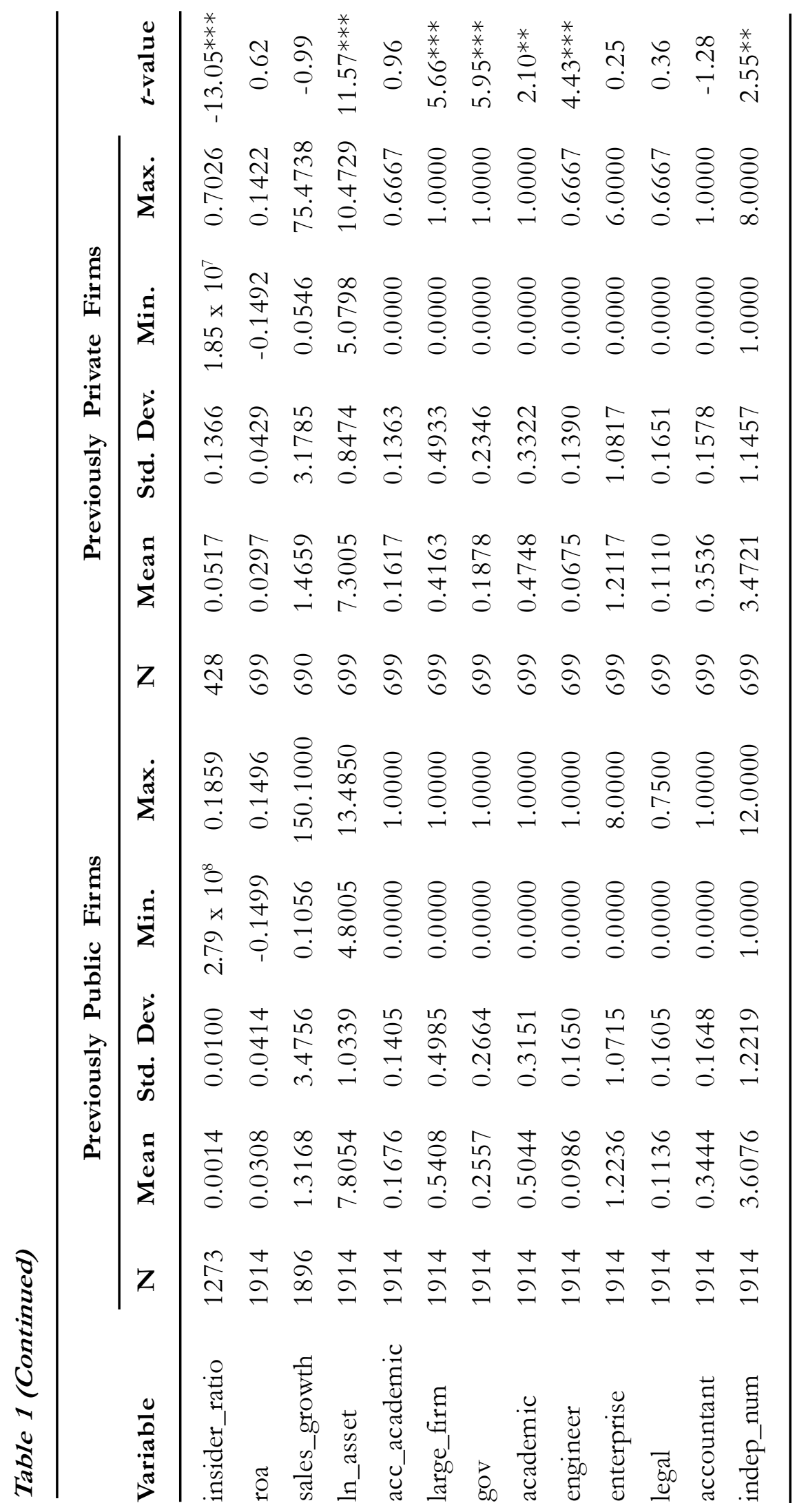


As suspected, public firms employ a higher percentage of government officials as directors, and this is highly significant at 1 percent level. Interestingly, we find that SOE firms actually hire more independent directors from academia than do private firms. This might be explained by the fact that the SOE firms in China usually could offer more publicity and fame on media to the independent directors than could private firms. Besides, the academics may be enticed to run government projects pertaining to the firm in which they are involved, which pay much more than their salaries as professors or researchers. Likewise, a significantly higher proportion of directors with engineering background is found in public firms. Eventually, the number of independent directors is higher for public firms than that for private firms, which is significant at 5 percent level. We try to reconcile the univariate results that private firms have a smaller board, higher proportion of independent directors, but lower number of independent directors on the board. This basically indicates that due to the smaller size of private firms' boards, the smaller number of independent directors still constitutes a higher percentage of independent directors relative to the case of public firms. Next, we show the unrestricted correlations among variables in Table 2.

The correlation matrix shows that there are several highly correlated independent variables. Board size and the number of independent directors are found to have a high positive relation. Compensation for top three executives is also positively and highly correlated with compensation for top three directors. Subsequently, the proportion of directors with accounting professor background is highly and positively correlated with the proportion of directors who used to be (or are still) academia and the proportion of direc- tors who have accounting background. On the other hand, the proportion of directors who used to be (or are still) from academia is negatively and highly correlated with the proportion of directors who used to be (or are still) entrepreneurs. Due to several high correlations among independent variables, symptoms of multicollinearity might appear, and this is formally examined in the next stage of analysis.

To check for the possible multicollinearity problem, we run a preliminary regression of Tobin's $Q$ on all other variables as independent variables. If the variance inflation ratio (VIF) of a particular variable is found to be higher than a predetermined level, then the variable is deemed suffering from the multicollinearity problem. The predetermined level is calculated as follows:

$$
\text { Predetermined Level }=\frac{1}{1-\mathrm{R}^{2}}
$$

where $\mathrm{R}^{2}$ is the coefficient of determination of the regression.

The regression model for multicollinearity problem checking is constructed as follows:

$$
\begin{aligned}
& \mathrm{Q}_{\mathrm{it}}=\beta_{0}+\beta_{1} \text { ln_board_size } \mathrm{it}_{\mathrm{t}}+ \\
& \beta_{2} \text { ln_av_age }{ }_{\text {it }}+\beta_{3} \text { ln_av_edu }_{\mathrm{it}}+ \\
& \beta_{4} \text { duality }_{\text {it }}+\beta_{5} \text { indep_ratio }_{\text {it }}+ \\
& \beta_{6} \text { private }_{\text {it }}+\beta_{7} \text { ln_top_value }_{\text {it }}+
\end{aligned}
$$

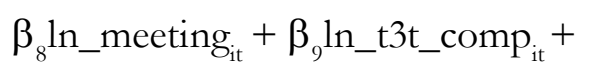

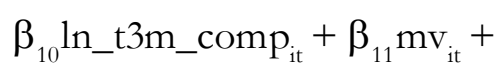

$$
\begin{aligned}
& \beta_{12} \mathrm{ROA}_{\mathrm{it}}+\beta_{13} \text { sales_growth }_{\mathrm{it}}+ \\
& \beta_{14} \text { ln_asset }_{\text {it }}+\beta_{15} \text { acc } \_ \text {academic }_{\text {it }}+ \\
& \beta_{16} \text { large_firm }_{\mathrm{it}}+\beta_{17} \mathrm{gov}_{\mathrm{it}}+ \\
& \beta_{18} \text { academic }_{\text {it }}+\beta_{19} \text { engineer }_{\text {it }}+
\end{aligned}
$$




$$
\begin{aligned}
& \beta_{20} \text { enterprise }_{\text {it }}+\beta_{21} \text { legal }_{\text {it }}+ \\
& \beta_{22} \text { accountant }_{\text {it }}+\beta_{23} \text { indep_num }{ }_{\text {it }}+ \\
& \varepsilon_{\text {it }}
\end{aligned}
$$

\section{where:}

$\mathrm{Q}=\quad$ Tobin's $\mathrm{Q}$,

Ln_board_size $=\log$ of the number of directors in the board,

Ln_av_age $=\quad \log$ of the average age of directors,

Av_edu $=\quad$ the proportion of directors who have college education or above,

Duality $=$ a dummy variable taking the value of 1 if $\mathrm{CEO}$ and Chairman is the same person, and 0 otherwise,

Indep_ratio $=$ the percentage of independent directors in the board,

Private $=$

a dummy variable taking the value of 1 if the firm is previously a private firm before IPO, and 0 if the firm is previously a public firm,

Ln_top_value $=\log$ of the shareholding by top three executives/ board members,

Ln_meeting $=\quad \log$ of the times of board meetings within the year,

Ln_t3b_comp $=\log$ of the compensation for top three directors,

Ln_t3m_comp $=\log$ of the compensation for top three executives,

MV = market value of the firm,

$\mathrm{ROA}=\quad$ return on assets,
Sales_growth $=$ the growth rate of the firm's sales,

Ln_asset $=\quad \log$ of the firm's assets,

Acc $\_$academic $=$the percentage of directors who have accounting professor background,

Large_firm $=\quad$ a dummy variable taking the value of 1 if it is a large firm, and 0 otherwise,

Gov $=\quad$ the percentage of directors who used to work as government officials,

Academic $=\quad$ the percentage of directors who came (or are still) from academia,

Engineer $=\quad$ the percentage of directors who have engineering background,

Enterprise $=\quad$ the percentage of directors who used to be (or are still) entrepreneurs,

Legal $=\quad$ the percentage of directors who used to be (or are still) lawyers,

Accountant $=$ the percentage of directors who have accounting background,

Indep_number $=$ the number of independent directors,

$i=$ firm $i$,

$\mathrm{t}=$ year $\mathrm{t}$.

Results of multicollinearity test are presented in Table 3 . The regression yields a coefficient of determination of 0.447 . Accordingly, the predetermined level (calculated by Equation 1) is 1.807, and this is then compared with each variable's VIF. 


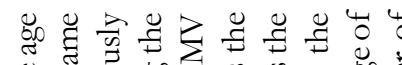

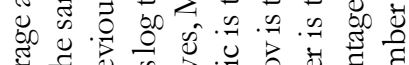

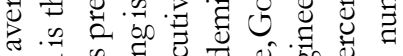

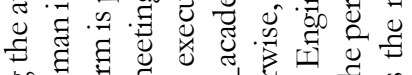

o.

㝴全

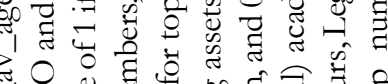

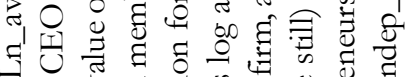

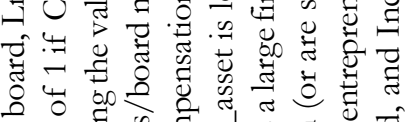

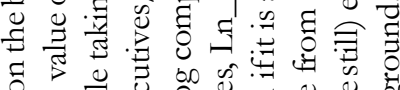

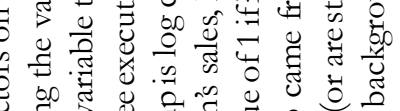

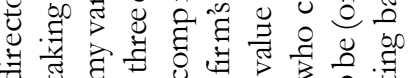

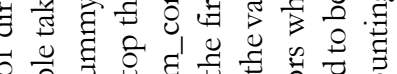

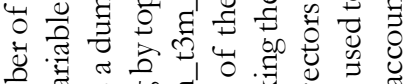

焉.

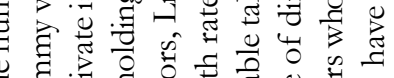

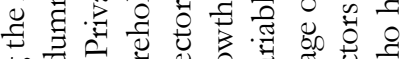

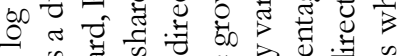

$\Leftrightarrow .2000$

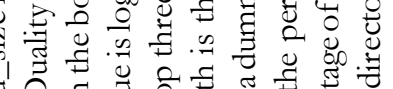

-

ठํ.0

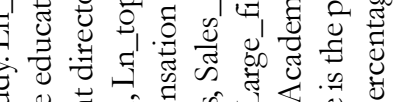

范 考 ही

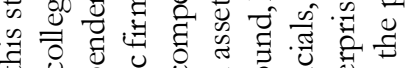

I 000

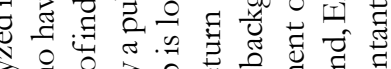

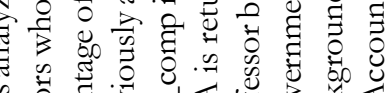

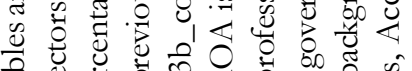

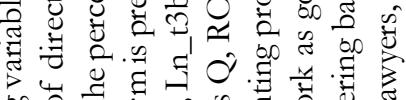

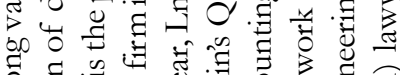

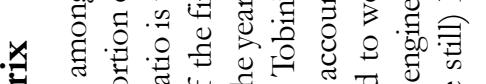

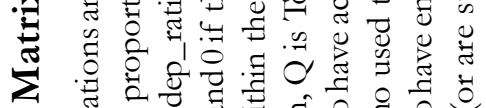

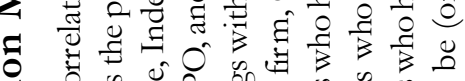

- 0 .

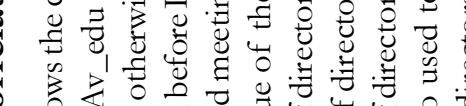

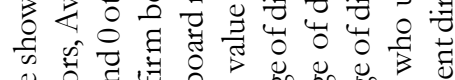

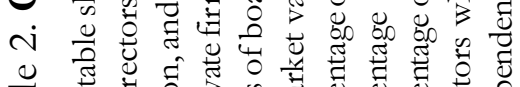

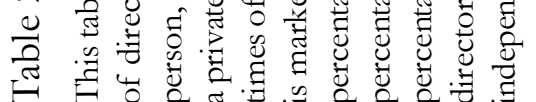

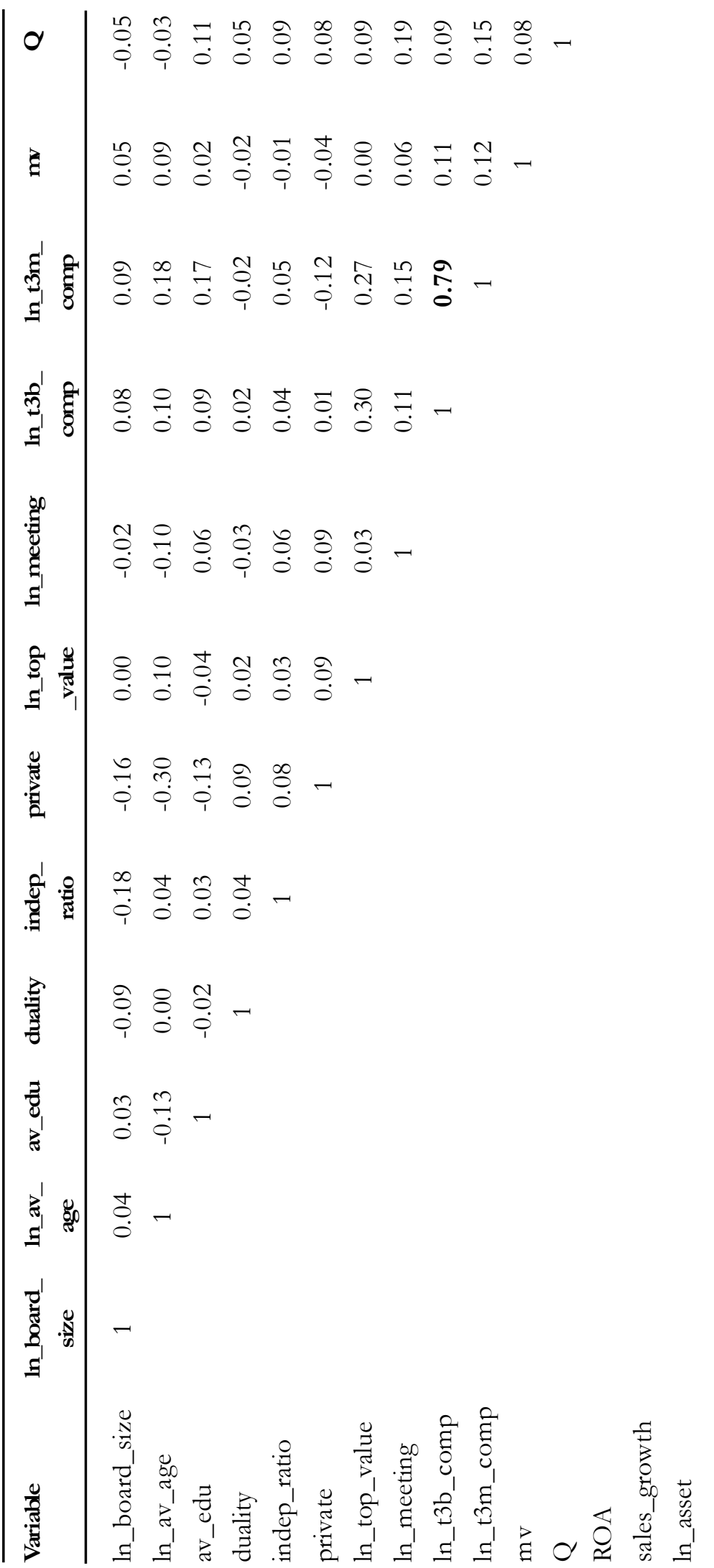


Gadjah Mada International Journal of Business - Maj-August, Vol 15, Na 2, 2013

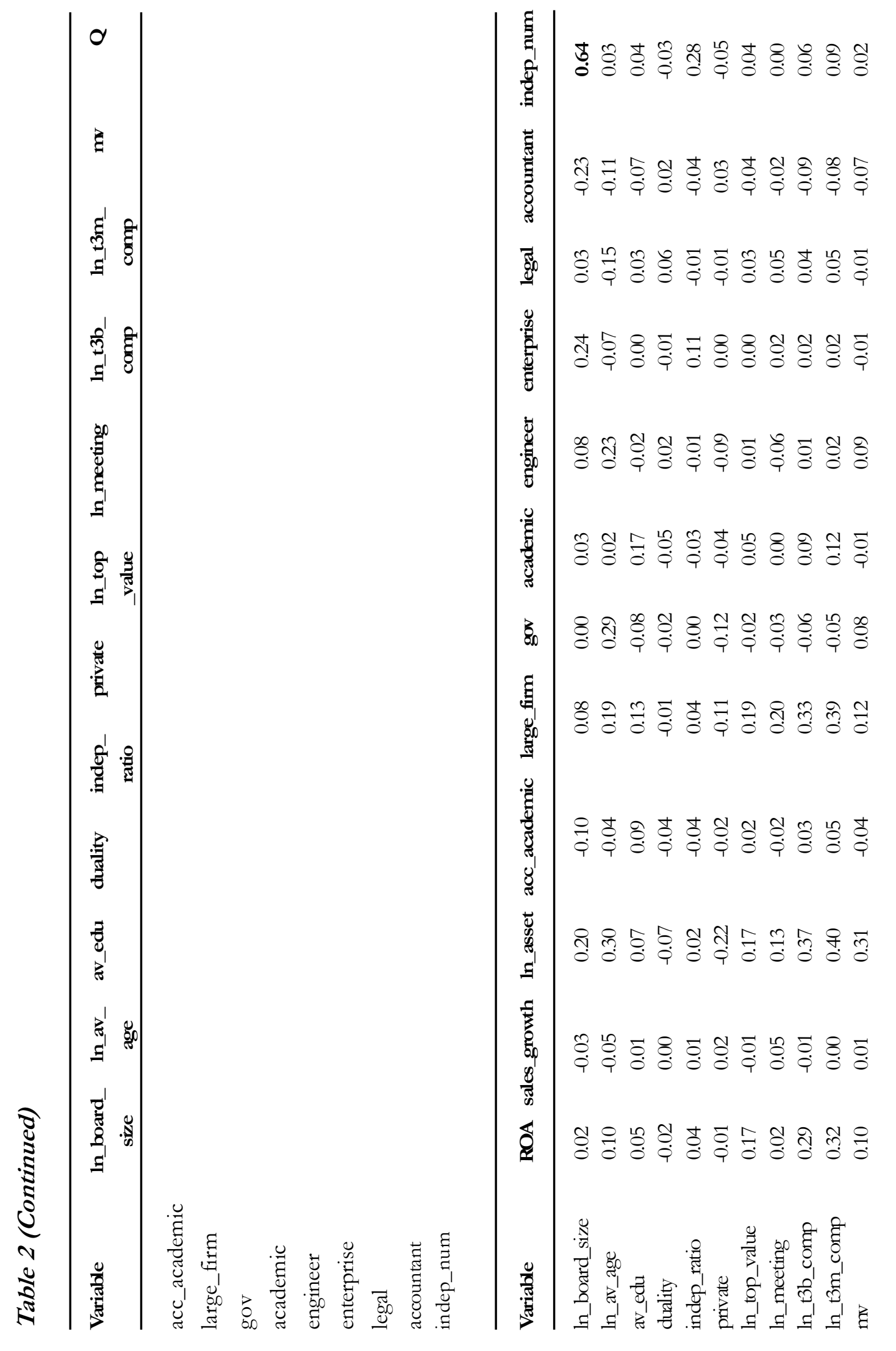




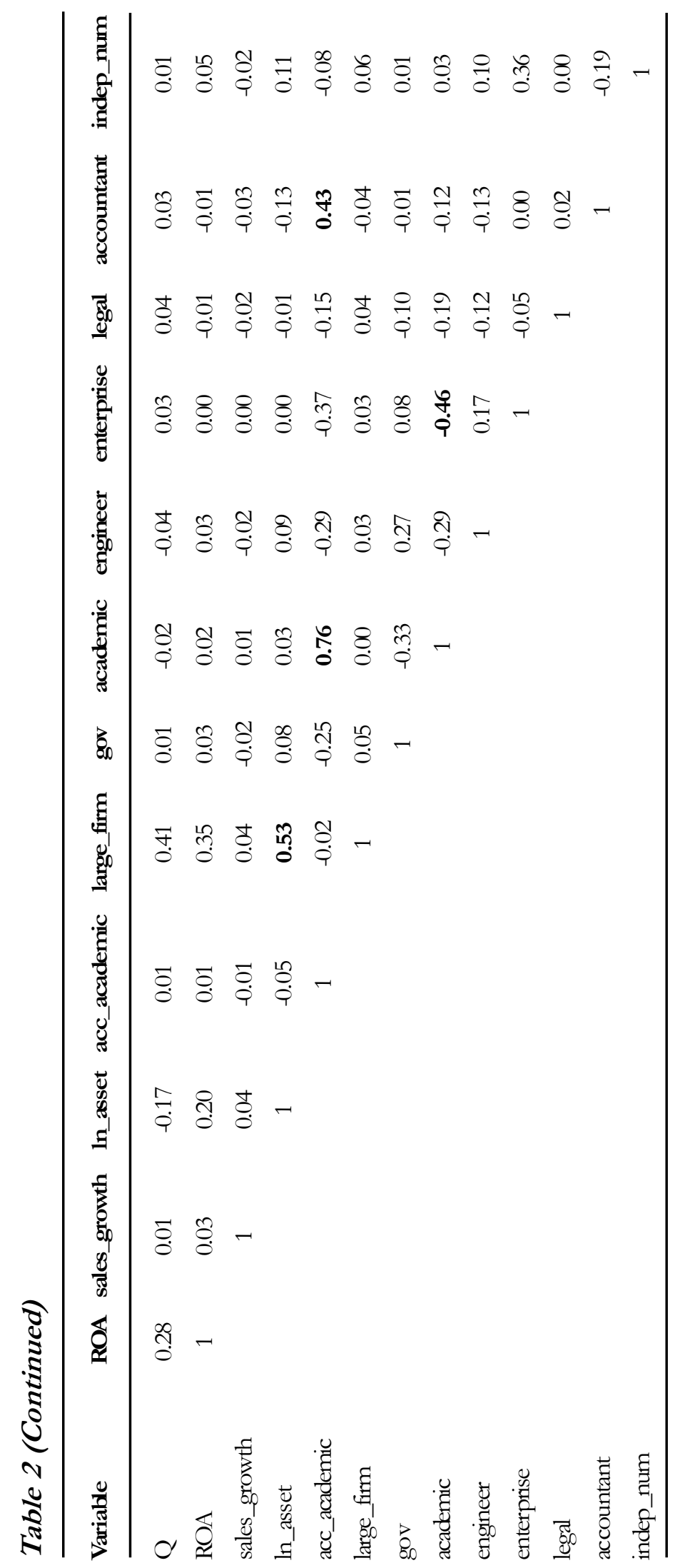




\section{Table 3. Multicollinearity Check Using VIF}

This table reports the results of preliminary regression to check for potential multicollinearity. Dependent variable is Tobin's Q. Independent variables are as follows. Ln_board_size is log the number of directors on the board, Ln_av_age is $\log$ the average age of directors, Av_edu is the proportion of directors with college education, Duality is a dummy variable taking the value of 1 if CEO and Chairman is the same person, and 0 otherwise, Indep_ratio is the percentage of independent directors on the board, Private is a dummy variable taking the value of 1 if the firm is previously a private firm before IPO, and 0 if the firm is previously a public firm, Ln_top_value is log shareholding by top three executives/board members, Ln_meeting is $\log$ the times of board meetings within the year, Ln_t3b_comp is log compensation for top three directors, Ln_t3m_comp is log compensation for top three executives, MV is market value of the firm, ROA is return on assets, Sales_growth is the growth rate of the firm's sales, Ln_asset is log assets, Acc_academic is the percentage of directors who have accounting professor background, Large_firm is a dummy variable taking the value of 1 if it is a large firm, and 0 otherwise, Gov is the percentage of directors who used to work as government officials, Academic is the percentage of directors who came from (or are still) academia, Engineer is the percentage of directors who have engineering background, Enterprise is the percentage of directors who used to be (or are still) entrepreneurs, Legal is the percentage of directors who used to be (or are still) lawyers, Accountant is the percentage of directors with accounting background, and Indep_number is the number of independent directors. $* * *, * *$, and $*$ denote significances at 1 percent, 5 percent, and 10 percent levels, respectively. VIF is variance inflation ratio.

\begin{tabular}{|c|c|c|c|}
\hline \multicolumn{4}{|c|}{ Dependent Variable: Tobin's Q } \\
\hline Independent Var. & Coefficient & $t$-value & VIF \\
\hline Intercept & $3.133 * * *$ & 2.61 & 0.0000 \\
\hline ln_board_size & $0.285^{* *}$ & 2.19 & 2.4214 \\
\hline ln_av_age & 0.224 & 0.77 & 1.4606 \\
\hline av_edu & $0.504 * * *$ & 3.91 & 1.1516 \\
\hline duality & 0.074 & 1.24 & 1.0348 \\
\hline indep_ratio & $2.030 * * *$ & 4.18 & 1.4632 \\
\hline private & $0.077 *$ & 1.63 & 1.2694 \\
\hline ln_top_value & $0.018 * *$ & 2.35 & 1.1602 \\
\hline ln_meeting & $0.420 * * *$ & 7.92 & 1.1074 \\
\hline ln_t3b_comp & -0.054 & -1.41 & 2.9336 \\
\hline ln_t3m_comp & $0.142 * * *$ & 3.36 & 3.1357 \\
\hline $\mathrm{mv}$ & $0.000 * * *$ & 10.82 & 1.1329 \\
\hline $\mathrm{ROA}$ & $4.491 * * *$ & 8.96 & 1.2338 \\
\hline sales_growth & 0.000 & 0.13 & 1.0150 \\
\hline ln_asset & $-0.758 * * *$ & -30.60 & 1.8078 \\
\hline acc_academic & 0.431 & 1.24 & 6.7643 \\
\hline large_firm & $1.469 * * *$ & 30.93 & 1.6363 \\
\hline gov & 0.131 & 1.60 & 1.3208 \\
\hline academic & -0.189 & -1.24 & 6.8208 \\
\hline engineer & -0.171 & -1.30 & 1.2689 \\
\hline enterprise & 0.006 & 0.27 & 1.6592 \\
\hline legal & 0.037 & 0.29 & 1.1989 \\
\hline accountant & -0.169 & -0.84 & 3.0513 \\
\hline indep_num & -0.031 & -1.26 & 2.5977 \\
\hline Adj. R-sq. & 0.442 & & \\
\hline
\end{tabular}


VIF-to-predetermined-level comparison provides evidence that ln_board_size, ln_t3b_comp, ln_t3m_comp, ln_asset, acc_academic, academic, accountant, and indep_num might be involved in the multicollinearity problem. This substantiates the conjectures offered by the correlation matrix in Table 2. In particular, board size seems to be collinear with the number of independent directors, compensation for top three executives tend to be collinear with compensation for top three directors, and the proportion of directors with accounting professor background is inclined to have multicollinearity with the proportion of directors who used to be (or still are) from academia and with the proportion of directors having accounting background. In an unreported test, we also utilize another estimate, which is the Eigenvalue analysis, and the results conclude similarly.

To remedy the multicollinearity problem, techniques employed are as follows. For the potential multicollinearity between $\log$ board size and the number of independent directors, we conduct the following regression:

Indep_num ${ }_{\mathrm{it}}=\alpha+\beta \ln \_$board_size ${ }_{\mathrm{it}}+\varepsilon_{\mathrm{it}} \ldots . . .(3)$

From the regression in Equation 3, we retain $\ln \_$board_size and $\varepsilon_{\text {it }}$ (instead of indep_num) to be used in subsequent analysis. Similarly, for the possible multicollinearity between compensation for top three executives and compensation for top three directors, we run the following regression:

$$
\begin{aligned}
\ln \_t 3 b \_c o m p \\
\text { it }
\end{aligned}=\begin{aligned}
\alpha+\beta \ln \_t 3 m \_c o m p \\
\text { it }
\end{aligned}
$$

From Equation 4, ln_t3m_comp and $\varepsilon_{\text {it }}$ are retained for further analysis. Subsequently, the potential multicollinearity between $\log$ assets and large firm dummy is handled using the following regression:

Large_firm $_{\mathrm{it}}=\alpha+\beta \ln \_$asset $_{\mathrm{it}}+\mathrm{e}_{\mathrm{it}} \ldots .$. (5)

where ln_asset and $\varepsilon_{\text {it }}$ from Equation 5 are retained.

Finally, we handle the possible multicollinearity among the proportion of directors who have accounting professor background, the proportion of directors from academia, and the proportion of directors with accounting background using the following regressions:

$$
\begin{aligned}
\text { Acc }_{\text {academic }}= & \alpha+\beta_{1} \text { academic }_{i t}+ \\
& \beta_{2} \text { accountant }_{\text {it }}+\varepsilon_{i t} \ldots . .(6)
\end{aligned}
$$

$$
\begin{aligned}
\text { Accountant }_{\mathrm{it}}= & \alpha+\beta_{1} \text { academic }_{\mathrm{it}}+ \\
& \beta_{2} \text { acc }_{\text {academic }_{\mathrm{it}}}+\varepsilon_{\mathrm{it}} \ldots \ldots .(7)
\end{aligned}
$$

where we retain Academic variable and the error terms from Equations 6 and 7 to be utilized in subsequent analysis.

Meanwhile, to control for possible heteroskedastic nature of panel data, we apply Davidson and MacKinnon's heteroskedastic-corrected robust standard errors to get parameter estimates in all regressions in our study.

\section{Multivariate Analysis}

The second approach to analyzing the relation between firm performance and firm governance for private and public firms is 
through multivariate regressions. We firstly conduct separate regressions for both types of firms using the following equation:

$$
\begin{aligned}
& \mathrm{Q}_{\mathrm{it}}=\beta_{0}+\beta_{1} \text { ln_board_size }{ }_{\mathrm{it}}+ \\
& \beta_{2} \text { r_indep_num }{ }_{\mathrm{it}}+\beta_{3} \text { ln_av }_{-} \text {age }{ }_{\mathrm{it}}+ \\
& \beta_{4} \text { av_edu }_{\text {it }}+\beta_{5} \text { duality }_{\text {it }}+ \\
& \beta_{6} \text { indep_ratio }_{\text {it }}+\beta_{7} \text { ln_top_value }{ }_{\text {it }}+ \\
& \beta_{8} \text { ln_meeting }_{\text {it }}+\beta_{9} \text { ln_t } 3 \mathrm{~m}_{-} \text {comp }_{\text {it }}+ \\
& \beta_{10} \text { r_ln_t3b_comp }{ }_{i t}+\beta_{11} \mathrm{mv}_{\text {it }}+ \\
& \beta_{12} \mathrm{ROA}_{\mathrm{it}}+\beta_{13} \text { sales_growth }_{\mathrm{it}}+ \\
& \beta_{14} \text { ln_asset }_{\text {it }}+\beta_{15} \text { r_large_firm }{ }_{\mathrm{it}}+ \\
& \beta_{16}{ }^{\mathrm{r}} \operatorname{gov}_{\mathrm{it}}+\beta_{17} \text { academic }_{\text {it }}+ \\
& \beta_{18} \text { r_acc_academic }{ }_{\text {it }}+ \\
& \beta_{19}{ }_{1} \_ \text {accountant }_{\text {it }}+\beta_{20} \text { engineer }_{\text {it }}+ \\
& \beta_{21} \text { enterprise }_{\mathrm{it}}+\beta_{22} \text { legal }_{\mathrm{it}}+\varepsilon_{\mathrm{it}} \ldots . .(8)
\end{aligned}
$$

where:

$$
\mathrm{Q}=
$$$$
\text { Tobin's Q, }
$$

Ln_board_size $=$ $\log$ of the number of directors in the board,

r_indep_number $=$ the number of independent directors, which is the residual of regression (3),

Ln_av_age $=\quad \log$ of the average age of directors,

$A v \_$edu $=\quad$ the proportion of directors who have college education or above,

Duality $=\quad$ a dummy variable taking the value of 1 if CEO and Chairman is the same person, and 0 otherwise,

Indep_ratio $=$ the percentage of independent directors in the board,
Ln_top_value $=\quad \log$ of the shareholding by top three executives / board members,

Ln_meeting $=\quad \log$ of the times of board meetings within the year,

Ln_t $3 \mathrm{~m} \_$comp $=\quad \log$ of the compensation for top three executives,

r_ln_t3b_comp $=\log$ of the compensation for top three directors, which is the residual of regression (4),

$\mathrm{MV}=$ market value of the firm,

$\mathrm{ROA}=$ return on assets,

Sales_growth $=$ the growth rate of the firm's sales,

Ln_asset $=$ $\log$ of the firm's assets,

r_large_firm $=$

Gov=

Academic $=$ a dummy variable taking the value of 1 if it is a large firm, and 0 otherwise, which is the residual of regression (5),

the percentage of directors who used to work as government officials,

the percentage of directors who came (or are still) from academia,

r_acc $\_$academic $=$the percentage of directors who have accounting professor background, which is the residual of regression (6),

r_accountant $=$ the percentage of directors who have accounting background, which is the residual of regression (7),

Engineer $=$ the percentage of directors who have engineering background, 
Enterprise $=\quad$ the percentage of directors who used to be (or are still) entrepreneurs,

Legal $=$

$\mathrm{i}=$ firm $\mathrm{i}$, and

$\mathrm{t}=$ year $\mathrm{t}$.

Model 1 of Table 4 shows the results for public firms. In the case of SOE firms, the evidence indicates that Tobin's Q is positively and significantly related to board size (substantiating Hypothesis 2B), the proportion of directors with college degrees or higher (confirming Hypothesis 10), the proportion of independent directors on the board (supporting Hypothesis 4), sharehold-ing by top-three executives/directors (supporting Hypothesis 8), the annual frequency of board meetings (confirming Hypothesis 3), compensation for top-three executives (consistent with Hypothesis 11), market value, and ROA. Surprisingly, Q is positively related to duality (not supporting Hypothesis 7), meaning that $\mathrm{CEO}$ and Chairman being the same person actually brings value to the previously SOE firms. This is perhaps contributed to by business or management culture in the SOE firms where the unity of command could hasten the decision-making process, particularly when dealing with top government officers. Meanwhile, Tobin's $Q$ is negatively associated with firm size. With respect to director characteristics, we find that directors with accounting background is positively linked to firm value (confirming Hypothesis 6), but only marginally significant at 10 percent level. Investors may perceive that public firms are still lacking in professional directors, especially those who understand and are skillful in finance or accounting.
Results for private firms are reported in Model 2 of Table 4. For private firms, Tobin's $\mathrm{Q}$ is positively and significantly related to the frequency of annual meetings (Hypothesis 3), compensation for top-three executives (Hypothesis 11), market value, and ROA. On the other hand, there is a negative relationship between Tobin's $Q$ and firm size as well as sales growth. Therefore, larger private firms with faster sales growth tend to have lower Tobin's Qs. However, we do not find any significant relation between Tobin's $Q$ and director characteristics for the case of private firms.

Subsequently, this study examines both types of firms simultaneously. Since we have numerous independent variables (23 independent variables excluding interaction variables), a stepwise technique is preliminarily run to exclude independent variables that do not meet a minimum $F$-statistics $p$-value $(\alpha)$ of 0.15 . The stepwise regression model employed is as follows:

$$
\begin{aligned}
& \mathrm{Q}_{\mathrm{it}}=\beta_{0}+\beta_{1} \text { ln_board_size }{ }_{\mathrm{it}}+
\end{aligned}
$$

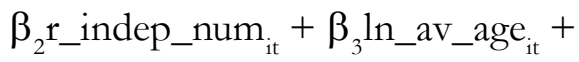

$$
\begin{aligned}
& \beta_{4} \mathrm{av} \_ \text {edu }_{\text {it }}+\beta_{5} \text { duality }_{\text {it }}+ \\
& \beta_{6} \text { indep_ratio }_{\text {it }}+\beta_{7} \text { private }_{\text {it }}+ \\
& \beta_{8} \ln \_ \text {top_value }{ }_{\text {it }}+\beta_{9} \ln \_ \text {meeting }_{\text {it }}+ \\
& \beta_{10} \text { ln_t3m_comp } \mathrm{it}_{\mathrm{it}}+ \\
& \beta_{11} \text { r_ln_t3b_comp }{ }_{i t}+\beta_{12} \mathrm{mv}_{\text {it }}+ \\
& \beta_{13} \text { ROA }_{\text {it }}+\beta_{14} \text { sales_growth }_{\text {it }}+ \\
& \beta_{15} \text { ln_asset }_{\text {it }}+\beta_{16} \text { r_large_firm }{ }_{\text {it }}+ \\
& \beta_{17} \text { r_gov }_{\text {it }}+\beta_{18} \text { academic }_{\text {it }}+ \\
& \beta_{19} \text { r_acc_academic } c_{i t}+ \\
& \beta_{20}{ }_{1} \text { accountant }_{\text {it }}+\beta_{21} \text { engineer }_{\text {it }}+ \\
& \beta_{22} \text { enterprise }_{\text {it }}+\beta_{23} \text { legal }_{\text {it }}+\varepsilon_{\text {it }} \ldots . . .(9)
\end{aligned}
$$


where:

$\mathrm{Q}=$

Tobin's Q,

Ln_board_size $=\log$ of the number of directors in the board,

r_indep_number= the number of independent directors, which is the residual of regression (3),

Ln_av_age $=$ $\log$ of the average age of directors,

Av_edu $=$

Duality $=$ the proportion of directors who have college education or above,

a dummy variable taking the value of 1 if CEO and Chairman is the same person, and 0 otherwise,

Indep_ratio $=$ the percentage of independent directors in the board,

Private $=$ a dummy variable taking the value of 1 if the firm is previously a private firm before IPO, and 0 if the firm is previously a public firm,

Ln_top_value $=\quad \log$ of the shareholding by top three executives/ board members,

Ln_meeting= $\log$ of the times of board meetings within the year,

Ln_t3m_comp $=\log$ of the compensation for top three executives,

r_ln_t3b_comp $=\log$ of the compensation for top three directors, which is the residual of regression (4),
$\mathrm{MV}=$

$\mathrm{ROA}=$

market value of the firm,

Sales_growth $=$ return on assets,

Ln_asset=

r_large_firm =

the growth rate of the firm's sales,

log of the firm's assets,

a dummy variable taking the value of 1 if it is a large firm, and 0 otherwise, which is the residual of regression (5),

Gov=

the percentage of directors who used to work as government officials,

Academic $=$ the percentage of directors who came (or are still) from academia,

r_acc_academic $=$ the percentage of directors who have accounting professor background, which is the residual of regression (6),

r_accountant $=$ the percentage of directors who have accounting background, which is the residual of regression (7),

Engineer $=\quad$ the percentage of directors who have engineering background,

Enterprise $=$ the percentage of directors who used to be (or are still) entrepreneurs,

Legal= the percentage of directors who used to be (or are still) lawyers,

$\mathrm{i}=$ firm $\mathrm{i}$, and

$\mathrm{t}=$ year $\mathrm{t}$. 


\section{Table 4. Separate Regressions for Previously Public and Previously Private Firms}

This table presents the results of separate regressions for previously public (Model 1) and previously private firms (Model 2). Dependent variable is Tobin's Q. Independent variables are as follows. Ln_board_size is log the number of directors on the board; r_indep_number is the number of independent directors, which is the residual of regression (3); Ln_av_age is log the average age of directors; Av_edu is the proportion of directors with college education; Duality is a dummy variable taking the value of 1 if CEO and Chairman is the same person, and 0 otherwise; Indep_ratio is the percentage of independent directors on the board; Private is a dummy variable taking the value of 1 if the firm is previously a private firm before IPO, and 0 if the firm is previously a public firm; Ln_top_value is $\log$ shareholding by top three executives/board members; Ln_meeting is log the times of board meetings within the year; Ln_t3m_comp is log compensation for top three executives; r_ln_t3b_comp is log compensation for top three directors, which is the residual of regression (4); $\mathrm{MV}$ is market value of the firm; ROA is return on assets; Sales_growth is the growth rate of the firm's sales; Ln_asset is log assets; r_large_firm is a dummy variable taking the value of 1 if it is a large firm, and 0 otherwise, which is the residual of regression (5); Gov is the percentage of directors who used to work as government officials; Academic is the percentage of directors who came from (or are still) academia; r_acc_academic is the percentage of directors who have accounting professor background, which is the residual of regression (6); r_accountant is the percentage of directors who have accounting background, which is the residual of regression (7); Engineer is the percentage of directors who have engineering background; Enterprise is the percentage of directors who used to be (or are still) entrepreneurs; and Legal is the percentage of directors who used to be (or are still) lawyers. $t$-stats are reported in parentheses. $* * *, * *$, and $*$ denote significances at 1 percent, 5 percent, and 10 percent levels, respectively.

\begin{tabular}{|c|c|c|}
\hline Dependent Var.: $\mathbf{Q}$ & Previously Public & Previously Private \\
\hline Independent Var. & (1) & (2) \\
\hline Intercept & $\begin{array}{l}-0.064 \\
(-0.05)\end{array}$ & $\begin{array}{c}6.322^{* * *} \\
(3.11)\end{array}$ \\
\hline ln_board_size & $\begin{array}{c}0.186^{*} \\
(1.77)\end{array}$ & $\begin{array}{l}-0.100 \\
(-0.53)\end{array}$ \\
\hline r_indep_num & $\begin{array}{l}-0.022 \\
(-0.75)\end{array}$ & $\begin{array}{l}-0.001 \\
(-0.03)\end{array}$ \\
\hline ln_av_age & $\begin{array}{l}0.429 \\
(1.28)\end{array}$ & $\begin{array}{l}0.063 \\
(0.12)\end{array}$ \\
\hline av_edu & $\begin{array}{c}0.568^{* * *} \\
(3.63)\end{array}$ & $\begin{array}{l}0.190 \\
(0.93)\end{array}$ \\
\hline duality & $\begin{array}{c}0.133^{*} \\
(1.83)\end{array}$ & $\begin{array}{l}-0.033 \\
(-0.35)\end{array}$ \\
\hline indep_ratio & $\begin{array}{c}1.748^{* * *} \\
(3.05)\end{array}$ & $\begin{array}{l}1.200 \\
(1.44)\end{array}$ \\
\hline ln_top_value & $\begin{array}{c}0.022 * * \\
(2.25)\end{array}$ & $\begin{array}{l}0.003 \\
(0.23)\end{array}$ \\
\hline ln_meeting & $\begin{array}{c}0.370^{* * *} \\
\quad(6.18)\end{array}$ & $\begin{array}{c}0.360 * * * \\
(3.61)\end{array}$ \\
\hline ln_t3m_comp & $\begin{array}{c}0.095^{* * *} \\
(2.89)\end{array}$ & $\begin{array}{c}0.091 * \\
(1.74)\end{array}$ \\
\hline r_ln_t3b_comp & $\begin{array}{l}-0.046 \\
(-1.11)\end{array}$ & $\begin{array}{l}-0.103 \\
(-1.29)\end{array}$ \\
\hline
\end{tabular}


Table 4 (Continued)

\begin{tabular}{|c|c|c|}
\hline Dependent Var.: Q & Previously Public & Previously Private \\
\hline Independent Var. & (1) & (2) \\
\hline $\mathrm{mv}$ & $\begin{array}{c}0.000^{* * *} \\
(9.98)\end{array}$ & $\begin{array}{c}0.000^{* * *} \\
(14.45)\end{array}$ \\
\hline ROA & $\begin{array}{c}3.765 * * * \\
(6.55)\end{array}$ & $\begin{array}{c}3.546 * * * \\
(3.90)\end{array}$ \\
\hline sales_growth & $\begin{array}{l}0.004 \\
(0.69)\end{array}$ & $\begin{array}{c}-0.018^{*} \\
(-1.65)\end{array}$ \\
\hline ln_asset & $\begin{array}{c}-0.329 * * * \\
(-13.03)\end{array}$ & $\begin{array}{c}-0.873 * * * \\
(-16.66)\end{array}$ \\
\hline r_large_firm & $\begin{array}{c}1.373 * * * \\
(25.32)\end{array}$ & $\begin{array}{c}1.420^{* * *} \\
(16.42)\end{array}$ \\
\hline gov & $\begin{array}{l}0.053 \\
(0.58)\end{array}$ & $\begin{array}{l}0.227 \\
(1.39)\end{array}$ \\
\hline academic & $\begin{array}{l}0.006 \\
(0.06)\end{array}$ & $\begin{array}{l}0.009 \\
(0.06)\end{array}$ \\
\hline r_acc_academic & $\begin{array}{l}0.984 \\
(1.50)\end{array}$ & $\begin{array}{l}0.498 \\
(0.39)\end{array}$ \\
\hline r_accountant & $\begin{array}{c}0.704 * \\
(1.80)\end{array}$ & $\begin{array}{l}-0.952 \\
(-1.45)\end{array}$ \\
\hline engineer & $\begin{array}{l}-0.098 \\
(-0.67)\end{array}$ & $\begin{array}{l}-0.367 \\
(-1.41)\end{array}$ \\
\hline enterprise & $\begin{array}{l}0.025 \\
(0.99)\end{array}$ & $\begin{array}{l}-0.012 \\
(-0.32)\end{array}$ \\
\hline legal & $\begin{array}{l}-0.016 \\
(-0.11)\end{array}$ & $\begin{array}{l}0.295 \\
(1.31)\end{array}$ \\
\hline $\mathrm{N}$ & 1,914 & 699 \\
\hline Adj. R-sq. & 0.410 & 0.628 \\
\hline$F$-value & $60.66 * * *$ & $53.80^{* * *}$ \\
\hline
\end{tabular}

Findings of the regression above are documented in Table 5. Results from the stepwise regression provide information that 12 independent variables fulfill the minimum criterion of $F$-statistic $p$-value of 0.15 . These variables are r_large_firm, ln_asset, mv, ROA, ln_meeting, ln_t3m_comp, indep_ratio, av_edu, ln_top_value, gov, ln_ board_size, and private. The 12 variables are subsequently utilized in the main regressions. The coefficients on the proportions of directors who have accounting, academic, accounting professorship, entrepreneurial, engineering, and law backgrounds are weakly related to Tobin's Q. 


\section{Table 5. Stepwise Regression Analysis}

This table shows the results of preliminary stepwise regression analysis to remove variables that do not meet the minimum requirement of $F$-statistics $p$-value of 0.15 . Dependent variable is Tobin's $Q$, and all other variables are independent variables. Ln_board_size is $\log$ the number of directors on the board; r_indep_number is the number of independent directors, which is the residual of regression (3); Ln_av_age is log the average age of directors; Av_edu is the proportion of directors who have college education; Duality is a dummy variable taking the value of 1 if CEO and Chairman is the same person, and 0 otherwise; Indep_ratio is the percentage of independent directors on the board; Private is a dummy variable taking the value of 1 if the firm is previously a private firm before IPO, and 0 if the firm is previously a public firm; Ln_top_value is $\log$ shareholding by top three executives/board members; Ln_meeting is log the times of board meetings within the year; $\mathrm{Ln} \_\mathrm{t} 3 \mathrm{~m} \_$comp is $\log$ compensation for top three executives; $r$ ln_t $3 \mathrm{~b} \_$comp is $\log$ compensation for top three directors, which is the residual of regression (4); MV is market value of the firm; ROA is return on assets; Sales_growth is the growth rate of the firm's sales; Ln_asset is log assets; r_large_firm is a dummy variable taking the value of 1 if it is a large firm, and 0 otherwise, which is the residual of regression (5); Gov is the percentage of directors who used to work as government officials; Academic is the percentage of directors who came from (or are still) academia; r_acc_academic is the percentage of directors who have accounting professor background, which is the residual of regression (6); r_accountant is the percentage of directors who have accounting background, which is the residual of regression (7); Engineer is the percentage of directors who have engineering background; Enterprise is the percentage of directors who used to be (or are still) entrepreneurs; and Legal is the percentage of directors who used to be (or are still) lawyers. ${ }^{* * *}$, **, and ${ }^{*}$ denote significances at 1 percent, 5 percent, and 10 percent levels, respectively.

\section{Dependent Var.}

\section{Tobin's Q}

\begin{tabular}{llll}
\hline Step & Independent Var. & Model R-sq. & $\boldsymbol{F}$-value \\
\hline 1 & r_large_firm & 0.336 & $1306.84^{* * *}$ \\
2 & ln_asset & 0.364 & $112.29^{* * *}$ \\
3 & mv & 0.393 & $124.56^{* * *}$ \\
4 & ROA & 0.415 & $92.90^{* * *}$ \\
5 & ln_meeting & 0.431 & $75.54^{* * *}$ \\
6 & ln_t3m_comp & 0.436 & $19.72^{* * *}$ \\
7 & indep_ratio & 0.440 & $18.15^{* * *}$ \\
8 & av_edu & 0.442 & $11.61^{* * *}$ \\
9 & ln_top_value & 0.443 & $5.32^{* *}$ \\
10 & gov & 0.444 & $2.98^{*}$ \\
11 & ln_board_size & 0.444 & 2.36 \\
12 & private & 0.445 & 1.93 \\
\hline
\end{tabular}


To analyze our panel data, we employ all panel regression techniques: (1) pooled, (2) random effects, and (3) fixed effects regressions. As reported in Table 6, we find that Breusch-Pagan's Lagrange Multiplier (LM) test statistic is not significant while Hausman specification test statistic is highly significant at 1 percent level, suggesting that the use of fixed effects models are the most efficient of all. Nonetheless, we present results from all models for comparison purposes. The regression equation used is:

$$
\begin{aligned}
& \mathrm{Q}_{\mathrm{it}}=\gamma_{\mathrm{i}}+\beta_{1} \ln \_ \text {board_size }_{\mathrm{it}}+ \\
& \beta_{2} \text { av_edu }_{\text {it }}+\beta_{3} \text { indep_ratio }_{\text {it }}+ \\
& \beta_{4} \text { private }_{\text {it }}+\beta_{5} \text { ln_top_value }{ }_{\text {it }}+ \\
& \beta_{6} \ln \_ \text {meeting }_{\mathrm{it}}+\beta_{7} \text { ln_t } 3 \mathrm{~m}_{-} \text {comp } \mathrm{itt}_{\mathrm{it}}+ \\
& \beta_{8} \mathrm{mv}_{\mathrm{it}}+\beta_{9} \mathrm{ROA}_{\mathrm{it}}+\beta_{10} \text { ln_asset }_{\mathrm{it}}+ \\
& \beta_{11} \text { r_large_firm }{ }_{\mathrm{it}}+\beta_{12} \mathrm{gov}_{\mathrm{it}}+ \\
& \beta_{13} \text { private }^{*} \text { ln_board_size }{ }_{i t}+ \\
& \beta_{14} \text { private } * \text { av_edu }{ }_{\text {it }}+ \\
& \beta_{15} \text { private }^{*} \text { indep_ratio }{ }_{\text {it }}+ \\
& \beta_{16} \text { private }^{*} \text { ln_top_value }{ }_{\text {it }}+ \\
& \beta_{17} \text { private }^{*} \ln \_ \text {meeting }{ }_{\text {it }}+ \\
& \beta_{18} \text { private }^{*} \text { ln_t } 3 \mathrm{~m}_{-} \text {comp } \mathrm{it}_{\mathrm{it}}+ \\
& \beta_{19} \text { private } * \text { gov }_{\text {it }}+\varepsilon_{\text {it }}
\end{aligned}
$$

where:

$\begin{array}{ll}\gamma= & \text { firm fixed effect, } \\ \mathrm{Q}= & \text { Tobin's } \mathrm{Q},\end{array}$

Ln_board_size $=\log$ of the number of directors in the board,

Av_edu $=\quad$ the proportion of directors who have college education or above,

Indep_ratio $=$ the percentage of independent directors in the board,
Private $=$

a dummy variable taking the value of 1 if the firm is previously a private firm before IPO, and 0 if the firm is previously a public firm,

Ln_top_value $=\log$ of the shareholding by top three executives/board members,

Ln_meeting $=\quad \log$ of the times of board meetings within the year,

Ln_t3m_comp $=\log$ of the compensation for top three executives,

$\mathrm{MV}=$ market value of the firm,

$\mathrm{ROA}=$ return on assets,

Ln_asset $=$ r_large_firm $=$ $\log$ of the firm's assets, a dummy variable taking the value of 1 if it is a large firm, and 0 otherwise, which is the residual of regression (5),

Gov $=\quad$ the percentage of directors who used to work as government officials,

$i=$ firm $i$,

$\mathrm{t}=$ year $\mathrm{t}$.

Regression results are presented in Table 6 . Models 1, 3, and 5 are produced by regressions without interaction variables. Fixed effects model (Model 5) yields a positive and significant coefficient on the private dummy, suggesting that after IPOs, previously private firms outperform previously public firms in China. This finding substantiates Hypothesis 1. In the wake of IPOs, the previously public firms might be faced with difficulties adjusting to professional business practices (e.g., hiring high-caliber executives and directors, revising company vision or policy, changing business models toward cus- 
tomer satisfaction, etc.) in order to establish and leverage competitive advantages. Since the Chinese government has emphasized the goal of extending the dominance of SOE firms in the most underpinning industries even after they go public, favorable policies and enormous assistance from the government to the SOE firms might create compla- cency, especially in early years after becoming publicly listed firms. On the other hand, business savvy and acumen, combined with efficiency and general economic freedom provided by the government have probably led the previously private firms to improve their values stronger and faster relative to their previously SOE firms counterparts.

\section{Table 6. Main Regression Results}

This table presents the evidence from main regressions. Dependent variable is Tobin's Q. Independent variables are as follows. Ln_board_size is log number of directors on the board; Av_edu is the proportion of directors with college education; Indep_ratio is the percentage of independent directors on the board; Private is a dummy variable taking the value of 1 if the firm is previously a private firm before IPO, and 0 if the firm is previously a public firm; Ln_top_value is $\log$ shareholding by top three executives/board members; Ln_meeting is log the times of board meetings within the year; Ln_t3m_comp is log compensation for top three executives; MV is market value of the firm; ROA is return on assets; Ln_asset is log assets; $r$ _large_firm is a dummy variable taking the value of 1 if it is a large firm, and 0 otherwise, which is the residual of regression Equation 5; Gov is the percentage of directors who used to work as government officials. Models 1 and 2 are based on pooled regressions, Models 3 and 4 random effects regressions, and Models 5 and 6 fixed effects regressions. All models employ Davidson and MacKinnon's heteroskedastic-robust parameter estimates. $t$-stats are reported in parentheses. ${ }^{* *}, * *$, and $*$ denote significances at 1 percent, 5 percent, and 10 percent levels, respectively.

\begin{tabular}{|c|c|c|c|c|c|c|}
\hline \multirow{2}{*}{$\begin{array}{l}\text { Dependent Var.: Q } \\
\text { Independent Var. }\end{array}$} & \multicolumn{2}{|c|}{ Pooled } & \multicolumn{2}{|c|}{ RE } & \multicolumn{2}{|c|}{ FE } \\
\hline & (1) & (2) & (3) & (4) & (5) & (6) \\
\hline Intercept & $\begin{array}{c}2.093^{* * *} \\
(6.80)\end{array}$ & $\begin{array}{c}2.192^{* * *} \\
(6.36)\end{array}$ & $\begin{array}{c}1.673^{* * *} \\
(4.88)\end{array}$ & $\begin{array}{c}1.824^{* * *} \\
(4.75)\end{array}$ & $\begin{array}{c}-4.905 * * * \\
(-4.64)\end{array}$ & $\begin{array}{c}-3.948^{* * *} \\
(-3.50)\end{array}$ \\
\hline ln_board_size & $\begin{array}{l}0.142 \\
(1.63)\end{array}$ & $\begin{array}{c}0.183^{*} \\
(1.85)\end{array}$ & $\begin{array}{l}0.120 \\
(1.23)\end{array}$ & $\begin{array}{l}0.159 \\
(1.43)\end{array}$ & $\begin{array}{l}-0.025 \\
(-0.12)\end{array}$ & $\begin{array}{l}-0.077 \\
(-0.33)\end{array}$ \\
\hline av_edu & $\begin{array}{c}0.467 * * * \\
(3.80)\end{array}$ & $\begin{array}{c}0.498^{* * *} \\
(3.23)\end{array}$ & $\begin{array}{c}0.472^{* * *} \\
(3.36)\end{array}$ & $\begin{array}{c}0.478^{* * *} \\
(2.73)\end{array}$ & $\begin{array}{l}0.469 \\
(1.21)\end{array}$ & $\begin{array}{l}0.060 \\
(0.14)\end{array}$ \\
\hline indep_ratio & $\begin{array}{c}1.766^{* * *} \\
(4.35)\end{array}$ & $\begin{array}{c}1.597^{* * * *} \\
(3.26)\end{array}$ & $\begin{array}{c}2.021 * * * \\
\quad(4.64)\end{array}$ & $\begin{array}{c}1.821^{* * *} \\
(3.48)\end{array}$ & $\begin{array}{c}2.858^{* * *} \\
(4.38)\end{array}$ & $\begin{array}{c}2.131^{* * *} \\
(2.78)\end{array}$ \\
\hline private & $\begin{array}{l}0.058 \\
(1.31)\end{array}$ & $\begin{array}{l}-0.377 \\
(-0.54)\end{array}$ & $\begin{array}{l}0.071 \\
(1.39)\end{array}$ & $\begin{array}{l}-0.593 \\
(-0.78)\end{array}$ & $\begin{array}{c}0.269^{*} \\
(1.78)\end{array}$ & $\begin{array}{c}-2.928^{* *} \\
(-2.24)\end{array}$ \\
\hline ln_top_value & $\begin{array}{c}0.017^{* *} \\
(2.32)\end{array}$ & $\begin{array}{c}0.024 * * \\
(2.45)\end{array}$ & $\begin{array}{c}0.024 * * * \\
(2.82)\end{array}$ & $\begin{array}{c}0.033 * * * \\
(2.87)\end{array}$ & $\begin{array}{c}0.188^{* * *} \\
(7.76)\end{array}$ & $\begin{array}{c}0.216^{* * *} \\
(7.04)\end{array}$ \\
\hline ln_meeting & $\begin{array}{c}0.401 * * * \\
(7.74)\end{array}$ & $\begin{array}{c}0.340^{* * *} \\
(5.68)\end{array}$ & $\begin{array}{c}0.478^{* * *} \\
\quad(8.72)\end{array}$ & $\begin{array}{c}0.415^{* * *} \\
\quad(6.56)\end{array}$ & $\begin{array}{c}0.558^{* * *} \\
(7.04)\end{array}$ & $\begin{array}{c}0.505^{* * *} \\
(5.64)\end{array}$ \\
\hline ln_t3m_comp & $\begin{array}{c}0.096^{* * *} \\
(3.45)\end{array}$ & $\begin{array}{c}0.091 * * * \\
(2.83)\end{array}$ & $\begin{array}{c}0.133^{* * *} \\
(4.27)\end{array}$ & $\begin{array}{c}0.123^{* * *} \\
(3.42)\end{array}$ & $\begin{array}{c}0.549 * * * \\
(8.87)\end{array}$ & $\begin{array}{c}0.511^{* * *} \\
(6.97)\end{array}$ \\
\hline $\mathrm{mv}$ & $\begin{array}{c}0.000 * * * \\
(10.12)\end{array}$ & $\begin{array}{c}0.000^{* * *} \\
(7.84)\end{array}$ & $\begin{array}{c}0.000^{* * *} \\
(9.00)\end{array}$ & $\begin{array}{c}0.000^{* * *} \\
(5.15)\end{array}$ & $\begin{array}{c}0.000^{* * *} \\
(8.12)\end{array}$ & $\begin{array}{c}0.000 * * * \\
(5.07)\end{array}$ \\
\hline
\end{tabular}


Gadjah Mada International Journal of Business - Maj-August, Vol 15, Na 2, 2013

Table 6 (Continued)

\begin{tabular}{|c|c|c|c|c|c|c|}
\hline \multirow{2}{*}{$\frac{\text { Dependent Var.: Q }}{\text { Independent Var. }}$} & \multicolumn{2}{|c|}{ Pooled } & \multicolumn{2}{|c|}{$\mathbf{R E}$} & \multicolumn{2}{|c|}{ FE } \\
\hline & (1) & (2) & (3) & (4) & (5) & (6) \\
\hline ROA & $\begin{array}{c}4.260^{* * * *} \\
(8.78)\end{array}$ & $\begin{array}{c}4.244^{* * * *} \\
(8.69)\end{array}$ & $\begin{array}{c}4.316^{* * *} \\
(8.39)\end{array}$ & $\begin{array}{c}4.306^{* * *} \\
(8.32)\end{array}$ & $\begin{array}{c}4.676^{* * *} \\
(6.33)\end{array}$ & $\begin{array}{c}4.666^{* * *} \\
(6.30)\end{array}$ \\
\hline ln_asset & $\begin{array}{c}-0.374 * * * \\
(-17.15)\end{array}$ & $\begin{array}{c}-0.376^{* * *} \\
(-17.10)\end{array}$ & $\begin{array}{c}-0.369 * * * \\
(-14.78)\end{array}$ & $\begin{array}{c}-0.370 * * * \\
(-14.70)\end{array}$ & $\begin{array}{c}0.216^{* *} \\
(2.48)\end{array}$ & $\begin{array}{c}0.219 * * \\
(2.51)\end{array}$ \\
\hline r_large_firm & $\begin{array}{c}1.487 * * * \\
(31.72)\end{array}$ & $\begin{array}{c}1.483^{* * *} \\
(31.60)\end{array}$ & $\begin{array}{c}1.438^{* * *} \\
(31.00)\end{array}$ & $\begin{array}{c}1.433 * * * \\
(30.86)\end{array}$ & $\begin{array}{c}1.050^{* * *} \\
(19.21)\end{array}$ & $\begin{array}{c}1.041 * * * \\
(19.01)\end{array}$ \\
\hline gov & $\begin{array}{l}0.135^{*} \\
(1.87)\end{array}$ & $\begin{array}{l}0.067 \\
(0.82)\end{array}$ & $\begin{array}{c}0.159^{*} \\
(1.95)\end{array}$ & $\begin{array}{l}0.087 \\
(0.94)\end{array}$ & $\begin{array}{c}0.323 * \\
(1.67)\end{array}$ & $\begin{array}{l}0.232 \\
(1.09)\end{array}$ \\
\hline private $*$ ln_board_size & & $\begin{array}{l}-0.137 \\
(-0.67)\end{array}$ & & $\begin{array}{l}-0.121 \\
(-0.53)\end{array}$ & & $\begin{array}{l}0.140 \\
(0.34)\end{array}$ \\
\hline private $*$ av_edu & & $\begin{array}{l}-0.078 \\
(-0.30)\end{array}$ & & $\begin{array}{l}-0.006 \\
(-0.02)\end{array}$ & & $\begin{array}{c}1.451 * * \\
(2.19)\end{array}$ \\
\hline private $*$ indep_ratio & & $\begin{array}{l}0.392 \\
(0.44)\end{array}$ & & $\begin{array}{l}0.516 \\
(0.54)\end{array}$ & & $\begin{array}{c}2.334^{*} \\
(1.71)\end{array}$ \\
\hline private $*$ ln_top_value & & $\begin{array}{l}-0.015 \\
(-1.01)\end{array}$ & & $\begin{array}{l}-0.019 \\
(-1.13)\end{array}$ & & $\begin{array}{l}-0.049 \\
(-1.25)\end{array}$ \\
\hline private $*$ ln_meeting & & $\begin{array}{c}0.245^{* *} \\
(2.10)\end{array}$ & & $\begin{array}{c}0.257 * * \\
(2.09)\end{array}$ & & $\begin{array}{l}0.188 \\
(1.12)\end{array}$ \\
\hline private $*$ ln_t3m_comp & & $\begin{array}{l}0.033 \\
(0.56)\end{array}$ & & $\begin{array}{l}0.051 \\
(0.80)\end{array}$ & & $\begin{array}{l}0.140 \\
(1.27)\end{array}$ \\
\hline private $*$ gov & & $\begin{array}{c}0.325^{*} \\
(1.86)\end{array}$ & & $\begin{array}{c}0.341 * \\
(1.75)\end{array}$ & & $\begin{array}{l}0.260 \\
(0.70)\end{array}$ \\
\hline $\mathrm{N}$ & 2,613 & 2,613 & 2,613 & 2,613 & 2,613 & 2,613 \\
\hline Firm fixed effects & No & No & No & No & Yes & Yes \\
\hline R-sq. & 0.443 & 0.445 & 0.435 & 0.437 & 0.684 & 0.687 \\
\hline Breusch-Pagan LM & & & 0.54 & 0.53 & & \\
\hline Hausman & & & & & $302.80^{* * *}$ & $313.01^{* * *}$ \\
\hline
\end{tabular}


With regard to results differentiating previously SOE firms from previously private firms, findings are documented in Models 2, 4 , and 6 , which contain interaction variables involving the private dummy and governance variables. We find evidence that board size is significantly and positively related to firm values of previously SOE firms, but this relation is not significant for previously private firms as shown by the insignificant coefficient on the interaction between private and board size variables. Adding more directors on the board clearly benefits the previously SOE firms as those directors would bring more expertise and experiences. The proportion of directors with college education is positively related to Tobin's Q for previously SOE firms, but only significant in pooled and random effects models. Accordingly, more educated directors might improve firm performance of previously SOE firms after going public. The interaction between the private dummy and av_edu variables has a significantly positive relationship with firm performance in fixed effects model, implying that the positive link of firm performance to college education has a stronger magnitude for private firms. Subsequently, the proportion of independent directors on the board has a significantly positive relation with firm performance for previously SOE firms. Independent directors indeed benefit those firms by contributing expertise as well as independent opinions. The coefficient on interaction variable involving a private dummy and the proportion of independent directors variables is also significantly positive. Thus, for a previously private firm, a higher proportion of independent directors on the board might be linked to an increased Tobin's Q with a higher magnitude than the equivalent increase for a previously SOE firm.
Inside ownership by top three executives or board members is positively and significantly associated with Tobin's Q for previously SOE firms. Higher shareholding by the top three executives or board members would lead to stronger sense of ownership, which in turn would increase firm value. However, the relation between firm performance and shareholding by top three executives or directors is not significant for previously private firms. Next, the relation between firm performance and the number of board meetings is also positive and highly significant for previously SOE firms. Likewise, this relation is significantly positive, with stronger intensity, in pooled and random effects models for previously private firms. Therefore, more board meetings are obviously valuable to both previously SOE and previously private firms, with the benefit being enhanced in the case of previously private firms.

The coefficients on average compensation for top three executives are positive and highly significant for previously SOE firms. This suggests that higher compensation might enhance executives' morale to manage previously $\mathrm{SOE}$ firms more eagerly so as to maximize shareholder wealth. Meanwhile, the interaction of average compensation to a private dummy is not significant. We also find that the proportion of directors who used to work as government officials has no impact on firm values of previously SOE firms. This implies that after IPOs, the external market plays a more pivotal role, and this eventually leads to more professional business processes and competition in the previously SOE firms. Meanwhile, when this variable is interacted with a private dummy, the coefficient on the interaction turns out to be significantly positive. Accordingly, previously private firms in China may enjoy the advantages of hiring 
directors with a government official or bureaucrat background, such as getting access to government projects, business channels, and other benefits. On the other hand, the role of this type of directors is less pronounced in the previously public firms since these firms basically had been controlled by the government, and had enjoyed all state projects, facilities, and information.

With respect to accounting performance, $\mathrm{ROA}$ is positively related to $\mathrm{Q}$, and as expected the relation is strongly significant in all regressions. Subsequently, the relation between firm size and firm performance is significantly positive. Fixed effects models find a positive relation between Tobin's Q and firm size, through both log assets and large-firm dummy variables.

\section{Robustness Check}

In this section, we investigate the possibility of endogeneity on the private dummy variable. It is likely that whether a Chinese firm was an SOE firm or a private firm right before our analysis period was related with how well it had performed in years before. Thus, as a robustness check, we utilize the following regression equation:

$$
\begin{aligned}
& \mathrm{Q}_{\mathrm{it}}=\beta_{0}+\beta_{1} \text { private }_{\mathrm{it}}+\beta_{2} \mathrm{av} \_\mathrm{edu}_{\mathrm{it}}+ \\
& \beta_{3} \text { indep_ratio }_{\text {it }}+\beta_{4} \text { ln_board_size }{ }_{i t}+ \\
& \beta_{5} \text { ln_top_value }{ }_{\text {it }}+\beta_{6} \text { ln_meeting }_{\text {it }}+ \\
& \beta \text { ln_t3m_comp } \mathrm{it}_{\mathrm{it}}+\beta_{8} \mathrm{mv}_{\mathrm{it}}+ \\
& \beta_{9} \mathrm{ROA}_{\text {it }}+\beta_{10} \text { ln_asset }_{\text {it }}+ \\
& \beta_{11} \text { r } \text { large_firm }_{\mathrm{it}}+\beta_{12} \mathrm{gov}_{\mathrm{it}}+\varepsilon_{\mathrm{it}}
\end{aligned}
$$

where:
$\mathrm{Q}=$
Tobin's Q,

Ln_board_size $=\log$ of the number of directors in the board,

Av_edu $=\quad$ the proportion of directors who have college education or above,

Indep_ratio $=$ the percentage of independent directors in the board,

Private $=\quad$ a dummy variable taking the value of 1 if the firm is previously a private firm before IPO, and 0 if the firm is previously a public firm,

Ln_top_value $=\log$ of the shareholding by top three executives/board members,

Ln_meeting $=\quad \log$ of the times of board meetings within the year,

Ln_t3m_comp $=\log$ of the compensation for top three executives,

$\mathrm{MV}=\quad$ market value of the firm,

$\mathrm{ROA}=\quad$ return on assets,

Ln_asset $=\quad \log$ of the firm's assets,

r_large_firm $=$ a dummy variable taking the value of 1 if it is a large firm, and 0 otherwise, which is the residual of regression (5),

Gov $=\quad$ the percentage of directors who used to work as government officials,

$\mathrm{i}=$ firm $\mathrm{i}$,

$\mathrm{t}=$ year $\mathrm{t}$.

We conduct two regression models: (1) two-stage least squares (2SLS) and (2) limited information maximum likelihood (LIML) methods. Using regression Equation 11, a private dummy variable is instrumented by 
lagged values of Tobin's Q (first and second lags). If the private dummy is indeed endogenous, thereby being related to previous periods' Tobin's $Q$, then the coefficient on $\beta_{1}$ should be significant. This approach to checking for potential endogeneity has been recommended by Bateman and Strasser (1983) and used in prior research (Davidson et al. 1997, among others).

\section{Table 7. Robustness Check}

This table reports the robustness check regarding potential endogeneity. Dependent variable is Tobin's Q. Independent variables are as follows. Private is a dummy variable taking the value of 1 if the firm is previously a private firm before IPO, and 0 if the firm is previously a public firm; Ln_board_size is $\log$ the number of directors on the board; Av_edu is the proportion of directors who have college education; Ln_top_value is log shareholding by top three executives/ board members; Ln_meeting is log the times of board meetings within the year; Ln_t3m_comp is log compensation for top three executives; MV is market value of the firm; ROA is return on assets; Ln_asset is log assets; r_large_firm is a dummy variable taking the value of 1 if it is a large firm, and 0 otherwise, which is the residual of regression (5); Gov is the percentage of directors who used to work as government officials. Private dummy variable is instrumented with lagged values of Tobin's Q (lag 1 and lag 2). $t$-stats are reported in parentheses. $* * *, * *$, and $*$ denote significances at 1 percent, 5 percent, and 10 percent levels, respectively.

\begin{tabular}{lcc}
\hline Dependent Var.: Q & 2SLS & LIML \\
Independent Var. & $\mathbf{( 1 )}$ & $\mathbf{( 2 )}$ \\
\hline Intercept & 75.942 & 354.629 \\
& $(0.48)$ & $(0.21)$ \\
private & -46.029 & -224.746 \\
& $(-0.45)$ & $(-0.21)$ \\
ln_board_size & -9.417 & -47.089 \\
& $(-0.44)$ & $(-0.20)$ \\
av_edu & -16.370 & -84.203 \\
& $(-0.42)$ & $(-0.20)$ \\
indep_ratio & 19.110 & 87.980 \\
& $(0.46)$ & $(0.21)$ \\
ln_top_value & 0.925 & 4.484 \\
& $(0.46)$ & $(0.21)$ \\
ln_meeting & 8.419 & 40.597 \\
& $(0.46)$ & $(0.21)$ \\
ln_t3m_comp & -2.919 & -14.661 \\
& $(-0.43)$ & $(-0.20)$ \\
mv & 0.000 & 0.000 \\
ROA & $(0.56)$ & $(0.22)$ \\
ln_asset & 68.099 & 289.033 \\
& $(0.54)$ & $(0.21)$ \\
& -5.255 & -23.317 \\
& $(-0.51)$ & $(-0.21)$
\end{tabular}


Table 7 (Continued)

\begin{tabular}{lcc}
\hline $\begin{array}{l}\text { Dependent Var.: } \mathbf{Q} \\
\text { Independent Var. }\end{array}$ & 2SLS & LIML \\
\hline r_large_firm & $\mathbf{( 1 )}$ & $\mathbf{( 2 )}$ \\
\hline & -0.265 & -5.022 \\
gov & $(-0.08)$ & $(-0.16)$ \\
& -8.080 & -39.944 \\
& $(-0.44)$ & $(-0.21)$ \\
N & & \\
R-sq. & 871 & 871 \\
F-value & 0.002 & 0.000 \\
\end{tabular}

As reported in Table 7, there is no significant relation between firm performance and the private dummy (instrumented by two lagged values of firm performance) in both 2SLS and LIML models. Therefore, panel data regression techniques, as employed in the previous section, are more appropriate to examine the association of firm performance to the private dummy and all other explanatory variables. Moreover, the results of Table 7 imply that endogeneity should not be of concern in our study.

\section{Conclusion}

This study examines the corporate governance of Chinese listed firms. Using 871 firms comprised of 699 observations of previously private firms and 1,914 observations of previously public firms, we find that there are differences between previously private firms and previously public firms, not only in their corporate governance but also in the relation between firm performance and board characteristics, after they go public. Theoretically, listed firms are conjectured to be homogenous with respect to their board characteristics and corporate governance, but interestingly our findings show significant dif- ferences in various aspects of governance and board characteristics. Our study contributes to the literature on corporate governance systems in China. Specifically, this paper sheds light on the differences in corporate governance between previously private firms and previously SOE firms after they both get listed on the Chinese stock markets.

Our findings are summarized as follows. We find that board size is smaller for previously private firms than for previously public firms. Directors of previously private firms are on average younger. Meanwhile, the proportion of directors with college education or higher is significantly lower for previously private firms. It is also evident that previously private firms are more likely to use the duality system (CEO and Chairman being the same person) than do previously public firms. However, the proportion of independent directors on the board is significantly higher for previously private firms. Regarding insider ownership, shareholding by top three executives or directors is significantly higher for previously private firms. Market value of equity of previously public firms is much larger than that of previously private firms. However, Tobin's Q of previously private firms is significantly higher, indicating that 
previously private firms perform better than do previously SOE firms in creating value for shareholders. Sales growth is significantly higher for previously private firms, implying that they have the potential and therefore grow faster. Meanwhile, previously SOE firms employ a higher percentage of government officials as directors, and this is consistent with the common practice in China. Interestingly, we find that previously SOE firms actually hire more independent directors from academia than do private firms. Likewise, a significantly higher proportion of directors with engineering background is found in previously SOE firms. Finally, the number of independent directors is marginally higher for previously SOE firms than that for previously private firms. Due to the smaller board size of previously private firms, the smaller number of independent directors still constitutes a higher percentage of independent directors relative to the case of previously SOE firms.

We investigate the relation between board characteristics and firm performance measured as Tobin's $Q$ for sample firms. We find evidence that previously private firms outperform previously SOE firms in China after IPOs. In the wake of IPOs, previously SOE firms might be having difficulties adjusting to professional business practices (e.g., hiring high-caliber executives and directors, revising company vision or policy, changing business models toward customer satisfaction, etc.) to build and extend competitive advantages. In addition, favorable policies and assistance from the government to the SOE firms might have engendered complacency, especially in the early years after becoming listed firms. On the other hand, professional savvy and acumen, combined with efficiency and favorable business climate created by the government have probably led the previously private firms to improve their values more strongly and faster.

Our findings show that board size is positively related to the firm values of previously SOE firms, but this relation is not significant for previously private firms. The proportion of directors with college education is positively related to Tobin's Q for previously SOE firms, and this positive link is even stronger in magnitude for previously private firms. Furthermore, board independence has a positive relation with firm performance for previously SOE firms. For a previously private firm, a higher percentage of independent directors on the board is linked to an increased Tobin's Q with a higher magnitude than the equivalent increase for a previously SOE firm. Shareholding by top three executives or directors is positively associated with Tobin's $Q$ for previously SOE firms. However, the relation between firm performance and inside ownership by top three executives or board members is not significant for previously private firms. There is a positive relation between firm performance and the number of board meetings for both types of firms, with stronger intensity for previously private firms.

We also find a positive association between firm performance and average compensation for top three executives for previously SOE firms, but not for previously private firms. Eventually, the proportion of directors who used to work as government officials has no relation with firm performance of previously SOE firms, which suggests that after IPOs, the external market plays a more pivotal role that leads to more professional business practices in those firms. On the other hand, this relation is significantly positive for previously private firms. Accordingly, previously private firms in China may reap ben- 
efits of hiring directors with a government official or bureaucrat background, such as getting access to government projects, business acquaintances, etc. For previously SOE firms, the advantages of employing this type of directors is less pronounced as these firms basically had been controlled by the government, and had enjoyed all government projects, facilities, and information.

\section{References}

Aharony, J., C. J. Lee, and T. J. Wong. 2000. Financial packaging of IPO firms in China. Journal of Accounting Research 38: 103-126.

Allen, F., J. Qian, and M. Qian. 2005. Law, finance, and economic growth in China. Journal of Financial Economics 77: 57-116.

Bai, C., D. Li, Z. Tao, and Y. Wang. 2000. A multitask theory of state enterprise reform. Journal of Comparative Economics 28: 716-738.

Bai, C., Q. Liu, and F. Song. 2004. Bad news or good news: Propping and tunneling evidence from China. Working Paper. University of Hong Kong.

Bai, C., Q. Liu, J. Lu, F. Song, and J. Zhang. 2004. Corporate governance and market valuation in China. Journal of Comparative Economics 32: 519-616.

Bateman, T., and S. Strasser. 1983. A cross-lagged regression test of the relationship between job tension and employee satisfaction. Journal of Applied Psychology 68: 439-445.

Brickley, J., and C. James. 1987. The takeover market, corporate board composition, and ownership structure. Journal of Law and Economics 30: 161- 180.

Byrd, J., and K. Hickman. 1992. Do outside directors monitor managers? Evidence from tender offer bids. Journal of Financial Economics 32: 195-207.

Cai, H., Q. Liu, and G. Xiao. 2005. Does competition encourage unethical behavior? The case of Chinese corporate profit hiding. Working Paper. University of California at Los Angeles and University of Hong Kong.

Cichello, M. 2005. The impact of firm size on pay-performance sensitivities. Journal of Corporate Finance 11: 609-627.

Conger, J., D. Finegold, and E. Lawler. 1998. Appraising boardroom performance. Harvard Business Review 76: 136-148.

Core, J., R. Holthausen, and D. Larcker. 1999. Corporate governance, chief executive officers compensation, and firm performance. Journal of Financial Economics 51: 371-406.

Coughlan, A., and R. Schmidt. 1985. Executive compensation, managerial turnover, and firm performance: An empirical investigation. Journal of Accounting and Economics 7: 43-66.

Chan, D. H., J. P. Fan, and T. J. Wong. 2004. Do politicians jeopardize professionalism? Decentralization and the structure of Chinese corporate boards. Working Paper. Shanghai University of Finance and Economics and Chinese University of Hong Kong.

Che, J., and Y. Qiang. 1998. Insecure property rights and government ownership of firms. Quarterly Journal of Economics 113: 467-496. 
Chen, X., C. J. Lee, and J. Li. 2003. Chinese Tango: Government assisted earnings management. Working Paper. Hong Kong University of Science and Technology and Tsinghua University.

Davidson, W., N. Rangan, and S. Rosenstein. 1997. Regulation and systematic risk in electric utility industry: A test of the buffering hypothesis. Financial Review 32: 163-184.

Denis, D., and J. McConnell. 2003. International corporate governance. Journal of Financial and Quantitative Analysis 38: 1-36.

Denis, D., and A. Sarin. 1999. Ownership and board structures in publicly traded corporations. Journal of Financial Economics 52: 187-224.

Fama, E., and M. Jensen. 1983. Separation of ownership and control. Journal of Law and Economics 26: 301-25.

Fan, J. P., T. J. Wong, and T. Zhang. 2007. Politically-connected CEOs, corporate governance and postIPO performance of China's partially privatized firms. Journal of Financial Economics 84: 330-357.

Firth, M., P. Fung, and O. Rui. 2008. Ownership, governance mechanisms, and agency costs in China's listed firms. Journal of Asset Management 9: 90-101.

Friedman, E., S. Johnson, and T. Mitton. 2003. Propping and tunneling. Journal of Comparative Economics 31: 732-750.

Gao, L., and G. Kling. 2008. Corporate governance and tunneling: Empirical evidence from China. PacificBasin Finance Journal 16: 591-605.

Gibson, M. S., 2003. Is corporate governance ineffective in emerging markets? Journal of Financial and Quantitative Analysis 38: 231-250.

Heaney, R. 2009. The size and composition of corporate boards in Hong Kong, Malaysia, and Singapore. Applied Financial Economics 19: 1029-41.

Hermalin, B., and M. Weisbach. 2003. Boards of directors as an endogenously determined institutions: A survey of the economic literature. Economic Policy Review 9: 7-26.

Jensen, M., and K. Murphy. 1990. Performance pay and top-management incentives. Journal of Political Economy 98: 225-262.

Jensen, M., 1993. The modern industrial revolution, exit, and the failure of internal control systems. Journal of Finance 48: 831-880.

Johnson, S., P. Boone, A. Breach, and E. Friedman. 2000. Corporate governance in the Asian financial crisis. Journal of Financial Economics 58: 141-186.

Johnson, S., E. Glaeser, and A. Shleifer. 2001. Coase versus the Coasians. Quarterly Journal of Economics 116: 853-899.

Johnson, S., R. La Porta, F. Lopez de Silanes, and A. Shleifer. 2000. Tunneling. American Economic Review 90: 22-27.

Kato, T., and C. Long. 2005. CEO turnover, firm performance, and enterprise reform in China: Evidence form new micro data. Discussion Paper. Institute for the Study of Labor.

Kroszner, R., and P. Strahan. 2001. Bankers on boards: Monitoring, conflicts of interest, and lender liability. Journal of Financial Economics 62: 415-452.

La Porta, R., F. Lopez de Silanes, A. Shleifer, and R. Vishny. 1997. Legal determinants of external finance. Journal of Finance 52: 1131-1150. 
La Porta, R., F. Lopez de Silanes, A. Shleifer, and R. Vishny. 1998. Law and finance. Journal of Political Economy 106: 1112-1155.

La Porta, R., F. Lopez de Silanes, and A. Shleifer. 1999. Corporate ownership around the world, Journal of Finance 54: 471-517.

La Porta, R., F. Lopez de Silanes, A. Shleifer, and R. Vishny. 2002. Investor protection and corporate valuation. Journal of Finance 57: 1147-1170.

Lipton, M., and J. Lorsch. 1992. A modest proposal for improved corporate governance. Business Lawyer 48: 59-77.

Liu, Q., and W. Xu. 2005. The deals are where the deal opportunities are: Evidence from China's emerging M\&A markets. Working Paper. University of Hong Kong.

Lu, T., J. Zhong, and J. Kong. 2009. How good is corporate governance in China. China and World Economy 17: 83-100.

Morck, R., A. Shleifer, and R. Vishny. 1988. Management ownership and market valuation: An empirical analysis. Journal of Financial Economics 20: 293-316.

Morck, R., and L. Steier. 2005. The global history of corporate governance: An introduction. NBER Working Paper: 11062.

Murphy, K. 1999. Executive compensation. In: Ashenfelter, O., and D. Card. (Eds.), Handbook of Labor Economics 3. North Holland: Amsterdam.

Pistor, K., and C. Xu. 2005. Governing stock markets in transition economies: Lessons from China. American Law and Economics Review 7: 184-210.

Qian Y., 1995. Reforming corporate governance and finance in China. In: Aoki, M., and H. Kim (Eds.), Corporate Governance in Transitional Economies. Washington D. C.: World Bank.

Rosenstein, S., and J. Wyatt. 1990. Outside directors, board independence, and shareholder wealth. Journal of Financial Economics 26: 175-184.

Shleifer, A., and R. Vishny. 1997. A survey of corporate governance. Journal of Finance 52: 737-783.

Shleifer, A., and R. Vishny. 1998. The Grabbing Hand: Government Pathologies and Their Cures. Cambridge: Harvard University Press.

Sun, Q., and W. Tong. 2003. China share issue privatization: The extent of its success. Journal of Financial Economics 70, 183-222

Tian, L., 2002. Government shareholding and the value of China's modern firms. Working Paper. London Business School.

Tong, S., and E. Junarsin. 2013. A comparison of Chinese state-owned enterprise firm's boards and private firm's boards. Working Paper. Central University of Finance and Economics and Universitas Gadjah Mada.

Vafeas, N. 1999. Board meeting frequency and firm performance. Journal of Financial Economics 53: 113142.

Wang, M., and G. Shao. 2007. The empirical analysis on blockholder ownership. Journal of Financial Research (Chinese) 2: 133-145.

Wei, Z., F. Xie, and S. Zhang. 2005. Ownership structure and firm value in China's privatized firms: 19912001. Journal of Financial and Quantitative Analysis 40: 87-108. 
Weisbach, M., 1988. Outside directors and CEO turnover. Journal of Financial Economics 20: 431-460.

$\mathrm{Xu}, \mathrm{X}$., and Y. Wang. 1999. Ownership structure and corporate governance in Chinese stock companies. China Economic Review 10: 75-98.

Yermack, D., 1996. Higher market valuation of companies with a small board of directors. Journal of Financial Economics 40: 185- 211. 